\title{
Films and TV: Viewing patterns and influence on behaviours of college students
}

Akhila Vasan

Follow this and additional works at: https://knowledgecommons.popcouncil.org/departments_sbsr-pgy

Part of the Broadcast and Video Studies Commons, Demography, Population, and Ecology Commons, Family, Life Course, and Society Commons, and the Gender, Race, Sexuality, and Ethnicity in Communication Commons How does access to this work benefit you? Let us know!

\section{Recommended Citation}

Vasan, Akhila. 2010. "Films and TV: Viewing patterns and influence on behaviours of college students," Health and Population Innovation Fellowship Program Working Paper no. 13. New Delhi: Population Council. 
This report is the result of a project entitled "Film and TV: Viewing patterns and influence on behaviours of college students," undertaken as part of the Health and Population Innovation Fellowship (HPIF) awarded to the author in 2005.

The HPIF programme is administered by the Population Council, New Delhi and is a continuation of the MacArthur Foundation's Fund for Leadership Development (FLD) fellowship programme that continued over the period 1995 to 2004. The Council is grateful to the MacArthur Foundation for its support to this programme.

The HPIF programme aims to support mid-career individuals who have innovative ideas, leadership potential, and the capacity to help shape policy and public debate in the field of population, reproductive health and rights in general, with a focus on two priority themes - maternal mortality and morbidity, and the sexual and reproductive health and rights of young people. Since the transfer of the programme to the Population Council through 2006, a total of 17 individuals have been supported under the HPIF programme.

For additional copies of this report, please contact:

Akhila Vasan
$53 / 543^{\text {rd }}$ Cross
Doctors' Colony
Konankunte
Bangalore-560062, India
Email: akhila.punch@gmail.com

Akhila Vasan

$53 / 543^{\text {rd }}$ Cross

Doctors' Colony

Bangalore-560062, India
Population Council

Zone 5A, Ground Floor

India Habitat Centre

Lodi Road, New Delhi 110003

Phone: 011-24642901/02

Email: info.india@popcouncil.org

Web site: http://www.popcouncil.org/asia/india.html

The Population Council is an international, non-profit, non-governmental organisation that seeks to improve the well-being and reproductive health of current and future generations around the world and to help achieve a humane, equitable and sustainable balance between people and resources. The Council conducts biomedical, social science and public health research, and helps build research capacities in developing countries.

Copyright @ 2010 Akhila Vasan

About the author: Akhila Vasan is a public health researcher with the Foundation for Research in Health Systems (FRHS), Bangalore. She has led qualitative studies on understanding young people's sexuality and sexual behaviour, their peer groups and friendship relations. She has a $\mathrm{PhD}$ from the National Institute of Mental health \& Neuroscience (NIMHANS) and has been part of NIMHANS' pioneering work on developing supportive supervision system for HIV counsellors in Karnataka. She is a member of the state unit of the People's Health Movement, the Janarogrya Andolana, Karnataka (JAAK)

Suggested citation: A. Vasan. 2010. "Films and TV: Viewing patterns and influence on behaviours of college students", Health and Population Innovation Fellowship Programme Working Paper, No 13, New Delhi: Population Council.

\section{A Population Council}


Films and TV:

Viewing patterns

and influence on

behaviours of

college students

Akhila Vasan

Fellow

Health and Population Innovation Fellowship Programme 


\section{Contents}

Introduction 1

Background 2

Global evidence of media influence on the behaviour of young people 2

Current issues in research on media influence 4

Evidence of media influence on the behaviour of young people in India 4

Content analysis of films 4

The media - a source of information on sexual and reproductive health 5

Media influence on behaviour 5

Study Setting 7

Methodology 8

The qualitative phase 8

The survey 9

Profile of respondents 12

Background characteristics __ 12

Individual behaviours

Teasing __ 13

Being in love_ 15

Engaging in sex 16

Cigarette smoking and alcohol consumption__ 16

$\begin{array}{ll}\text { Violence } & 17\end{array}$

Gender role attitudes __ 17

Media use patterns__ 17

Film and TV preferences _ 18

Context of exposure to mainstream films _ 20

Interpretation of situations from films _ 24

The film and film clip__ 24

Perceptions about gender roles__ 25

Interpretations of the acceptability of the woman's

act of hitting the man 27

Perceptions about the possible consequences of the woman's act___ 28 
Influence of the media, friends and the family 31

Influence of the media (films/TV) 31

Influence of friends 34

Influence of the family 35

Summary and conclusions 36

Acknowledgements 42

References 43

\section{List of tables}

Table 1: Participants enrolled for the qualitative phase by type of study course 8

Table 2: Number of young men and women participating in the qualitative study by method of data collection 9

Table 3: Percentage of respondents by selected background characteristics 12

Table 4: Percentage of respondents by individual behaviours

Table 5: Percentage of young men and young women reporting traditional notions of masculinity and femininity, as measured by the masculinity and femininity indexes 17

Table 6: Exposure of respondents to mainstream films and TV 18

Table 7: Percentage of respondents by preference for mainstream films and TV 18

Table 8: Percentage of respondents by venue and person/s with whom they watched films 21

Table 9: Responses of young men and women to questions about the film clip 25

Table 10: Percentage of young men reporting changes in selected behaviours influenced by the media, friends and family 40

Table 11: Percentage of young women reporting changes in selected behaviours influenced by the media, friends and family 41

iv $\mid$ Akhila Vasan 


\section{Introduction}

The past two decades have witnessed a growing interest among researchers in exploring the linkages between the media and the attitudes and behaviours of young people in India. In the context of the increasing incidence of HIV/AIDS, research on the sexuality and sexual behaviour of young people has highlighted the media as a significant source of information on reproductive and sexual health matters, and an important influence in young people's lives, particularly with respect to their interaction with the opposite sex (Vasan, Dinesh and Prashanth, 2004; Sodhi, Verma and Schensul, 2004; Belaku Trust, 2004). More recently, a youth needs survey undertaken in six states of India has found that substantial proportions of youth are exposed to the media; that for many youth, the media constitutes a leading source of sexual and reproductive health information; and that many youth, particularly men, have watched blue films or seen blue magazines (IIPS and Population Council, 2010).

Yet, very few studies have explored media use patterns among young people in terms of their media preferences, the context of media use, their interpretation of media content, and what they finally pick up and apply to their lives. A recent review of young people's sexual and reproductive health in India recommends the need for research aimed at understanding how the media influences young people and how young people negotiate these influences toward a safe adulthood (Jejeebhoy and Sebastian, 2004).

In this report, we present findings from a study intended to address what is known about the interaction between the media and young people. Specifically, it studies the influence of films and television (TV), the two most popular and accessible forms of the media among young people, as well as that of two other major influences, namely friends and the family, on the behaviours of college students of Kanakapura town in south Karnataka.

The objectives of the study are:

- To understand the level and context of young people's exposure to films and TV programmes, their film and TV preferences, and their interpretation of the media content of what they view.

- To understand whether or not young people make specific changes in behaviour subsequent to media exposure and, if so, to what extent.

- To explore how young people's media use patterns are associated with their involvement in certain behaviours, and their gender attitudes.

- To compare the influence of the media with that of friends and the family on these (selected) behaviours.

This report focuses on findings from a study that collected qualitative data and followed this with a cross-sectional survey on media exposure patterns in terms of young people's quantum and context of exposure to films and TV, their film/TV preferences, their interpretation of media (film) content, and the influence of films/TV on selected behaviours and gender attitudes. It also discusses the relative influence of friends and the family on these behaviours. 


\section{Background}

Social scientists and policy makers have long been concerned about the effects of the visual media (films and TV) on the attitudes and behaviours of young people. In particular, there are apprehensions about such exposure leading young people to risk-taking behaviours, including unsafe sex, alcohol use and violence.

\section{Global evidence of media influence on the behaviour of young people}

A considerable body of research from developed countries, particularly the US, suggests that the visual media influence a broad range of attitudes and behaviours among young people and may exacerbate risky practices. These studies have largely followed the "media-effects" model and explored the impact of the media on certain risk-taking behaviours such as engaging in sex, use of tobacco and alcohol, aggression and violence as well as such other behaviours as adopting new clothing styles and mannerisms, among others.

Studies conducted in the US, in the 1970s and 1980s, have shown a consistent relationship between media viewing and sexual behaviour. For example, a study that compared pregnant and non-pregnant girls found that girls who had become pregnant were more likely to have been watching soap operas prior to the pregnancy (Corder-Bolz, 1981), while another linked TV watching preferences to earlier initiation of sexual experience (Peterson and Kahn, 1984). Further, while viewing media with sexual content was observed to be positively linked to the viewer's permissive attitude toward pre-marital sex (Calfin, Carroll and Schmidt, 1993; Greeson and Williams, 1986), viewing more sexual content on television was found to increase the likelihood of engaging in sexual intercourse among teens (Brown and Newcomer, 1991).

Reviewing the impact of the media on adolescent sexual attitudes and behaviours, Escobar-Chaves and her colleagues found that exposure to $\mathrm{NC}-17$ rated films (a rating that prohibits admission of anyone who is 17 or under into a theatre) increased the likelihood of having multiple sexual partners, engaging in sex more often, testing positive for Chlamydia trachomatis, and having more negative attitudes toward condom use (Escobar-Chaves et al., 2004).

Based on their study with adolescents, Brown and her colleagues suggested that sexually explicit media act as a sexual "super peer" for teenage youth by serving as a readily available and accessible source of sexual information in the absence of significant counsel from family and school (Brown, Halpern and L'Engle, 2005). In a subsequent study, Brown et al used "sexual media diet" (SMD), an index of exposure to sexual content in the mass media, to explore media influences on adolescent sexual behaviour (Brown et al., 2006). Their longitudinal studies revealed that white adolescent girls in the top $20 \%$ of a random sample of SMD density when 12 to 14 years old, were more than twice as likely to have had sexual intercourse at age 14 to 16 as girls who had SMDs with densities in 
the lower $80 \%$. On the other hand, black teens reported a greater influence of "perceptions of their parents' expectations and their friends' sexual behaviour" than what they saw and heard in the media, a finding that points to the need to identify the cultural and social factors that account for apparently large variations in young people's vulnerability to media influence. Strasburger and Donnerstein also support the view that individual characteristics of young people such as race, ethnicity and family background have not been explored well enough to understand their relationship with media consumption and subsequent influence (Strasburger and Donnerstein, 1999).

The impact of the media on smoking among young people is another area that has received the attention of researchers. Indeed, available research evidence has led the National Cancer Institute to declare a causal relationship between exposure to smoking in films and initiation of smoking among youth (National Cancer Institute, 2008). More recently, a US study, using nationally representative samples and cross-sectional and longitudinal designs, observed that adolescents with high exposure to smoking in films were about three times more likely to try smoking or become smokers than those with low exposure to media smoking; the effect remained significant after controlling for a number of risk factors including personality, parenting style and socio-demographics (Heatherton and Sargent, 2009). The relationship between exposure to smoking in films and adolescent smoking has also been demonstrated across cultures (Hanewinkel and Sargent, 2008).

Among recent studies linking media portrayals of alcohol use to drinking onset among adolescents is a study which demonstrated a strong and statistically significant relationship between viewing alcohol use in films and drinking among teens in the US, even after controlling for a number of potential covariates; the relationship held for both crosssectional and longitudinal analyses (Sargent et al., 2006). A similar association between exposure to alcohol use in films and subsequent initiation of drinking by adolescents has been demonstrated in a cross-sectional study of US adolescents (Dalton et al., 2006) and a longitudinal study of German adolescents (Hanewinkel et al., 2008).

A review of studies in the US, linking exposure to violent media and aggression in adolescents and children, concluded that there is a "voluminous" body of research, including detailed cross-sectional and longitudinal studies, and meta-analyses, which demonstrates a "very clear" cause-and-effect relationship between media violence and reallife aggression (Strasburger and Donnerstein, 1999). Another review unequivocally noted that "violent imagery has short-term effects on arousal, thoughts, and emotions, increasing the likelihood of aggressive or fearful behaviour." However, evidence was less consistent in the case of older children and teenagers" partly due to methodological difficulties in linking behaviour with past viewing. Further, cross-sectional studies revealed a weak association between media violence and crime. The review also suggested a stronger influence of media violence on those with a predisposition for aggressive behaviour attributable to personality and/or situational factors (Browne and Hamilton-Giachritsis, 2005).

Media exposure is also seen as greatly influencing youth ideas of fashion, their choices of clothing and accessories. For example, a survey examining the self-perceived influence of the family, friends and the media on the clothing choice of 478 adolescents in the $6^{\text {th }}, 9^{\text {th }}$ and $12^{\text {th }}$ grades in two mid-western school districts in the US observed that black adolescents' choice of clothing and accessories was more likely to be influenced 
by the media than by family and friends, while white adolescents were more influenced by friends than by family and the media. Further, relative to clothing choices of all adolescents, the media was less influential with females, gained influence as adolescents age, and had almost twice as much influence on urban adolescents as rural (Wilson and MacGillivray, 1998). Schwartz found that the media can provide information on fashion, beauty and body satisfaction, and has the potential to provide positive images for adolescents in the process of their social development and emerging sense of identity, of which fashion decisions are a part (Schwartz, 2004).

\section{Current issues in research on media influence}

Critics of studies that hold the media responsible for risky behaviour in young people have called particular attention to the problems of inferring too much from statistical correlations. Further, they argue that the "media effects theories" treat young people as helpless victims of the media, failing to recognize them as active and savvy audiences who can tell the difference between fictional events and reality (Gauntlett, 1998).

Circumventing the latter argument, Steele proposed a "circular model," according to which individuals actively "select" the kinds of media content they wish to attend to, based on their "lived experiences" and "individual sense of identity" (Steele, 1999). This circular model recognizes young people as active audiences who also judge the messages and materials in the visual media in terms of credibility as well as suitability for their specific situations and daily-life experiences. Using Steele's model as a foundation, Hawk and his colleagues demonstrated that Dutch youth critically evaluate the "realism" or credibility of visual media products, and select the particular sexual and other materials to which they wish to pay attention (Hawk et al., 2006). Their findings also suggest that in females as compared to males, individual characteristics related to sexuality (motives, self-concepts, attitudes, and behaviours) are far more predictive of contact with sexual content in the media; among males, media consumption is more easily predicted by their evaluations of information about sexuality found in the particular media.

\section{Evidence of media influence on the behaviour of young people in India}

In India, research on the visual media has focused, by and large, on content analysis of media messages. These studies have assumed that the visual media significantly influence attitudes and behaviours and, as such, have sought to highlight the specific content areas in which the (negative) influence of the media is especially serious.

\section{Content analysis of films}

A content analysis of 20 news programmes, 20 fictionalised serials, and 100 commercials on Indian television conducted in 1988, over a three-week period, found stereotypic portrayals of men and women, with women often being portrayed as victims, care-givers/ homemakers and sex objects while men were presented as masters, doers and intellectuals (Behera, 1989). 
A more recent analysis of nine Hindi films randomly selected from 1997-1999 box office hits found that "moderate sexual violence is depicted as fun, enjoyable, and a normal expression of romantic love" (Ramasubramanian and Oliver, 2003) while a similar analysis of nine popular Kannada mainstream movies found the films to be replete with stereotypic ideas of "good" women and "bad" women linked with masculinity themes emphasizing men's control over women (Maslekar, Hamsa and Vasan, 2004).

In an analysis of films released in 2004-2005, the Burning Brain Society (BBS), a Chandigarh based non-governmental organization, found smoking depicted in $89 \%$ of the films released since the government banned direct and indirect forms of tobacco advertisement in 2004 (Goswami and Kashyap, 2006); this figure is significantly higher than that $(76 \%)$ reported by a 2003 World Health Organization (WHO) study of Indian films with tobacco imagery (WHO, 2003). The BBS study further revealed that smoking was associated with glamour and style where $75 \%$ of the films reviewed had the main character/ hero lighting up on screen. Brand placement was also widespread in scenes depicting smoking (Burning Brain Society, 2009).

Thus, without directly linking the content of these films to changes in people's attitudes and behaviours, these studies exemplify the kind of negative messages that people get from the visual media.

\section{The media-a source of information on sexual and reproductive health}

A more recent line of research aims at ascertaining the types of media from which young people obtain information on reproductive and sexual health matters. For example, a study of adolescent girls aged 13-17 in Haryana reported that for almost all, the leading source of information was the television (73\%) and/or the radio (37\%) (Singh, Devi and Gupta, 1999). Another study found the visual and printed media to be the main source of information on sexual matters for male college-going students in Bangalore (Vasan et al., 2004) while erotic materials (films and pornographic materials) formed the primary source of such information for low-income college boys in Mumbai (Abraham, 2001).

Yet another study of school-going adolescents in rural South Karnataka reported that boys and girls who cited the media (including the visual media) as their leading source of information had higher knowledge scores on reproductive and sexual health matters compared to those who cited parents, older siblings or peers as their main source of information (Kilaru, 2004). More recently, a multi-state study of youth behaviour in six states (Andhra Pradesh, Bihar, Jharkhand, Maharashtra, Rajasthan and Tamil Nadu found that friends and the media were the leading sources of information on sexual matters (IIPS and Population Council, 2010).

\section{Media influence on behaviour}

Studies in the Indian context have found that films and TV are an integral part of youth sub-culture. Focus group discussions conducted with 16-18 year olds in Delhi and Mumbai to understand the relevance of Indian cinema in the context of teenage lifestyles and behavior noted that films serve as a medium through which young people are 
presented with new ideas about dress codes, behavior or attitude which they often imitate and use in their daily interactions with friends and acquaintances (WHO, 2003). Films/ actors were part of everyday conversation with friends, evoking a desire to imitate the looks and mannerisms of their favourite actors. Goswami and Kashyap also found that imitating hairstyles, clothing and accessories of actors in popular films was widespread among both urban as well as rural youth (Goswami and Kashyap, 2006).

The WHO study further noted that "films have created a yearning for romance" and that to be labeled 'boyfriend' or 'girlfriend' implies "popularity, coolness and modernity". Findings also showed that 'gangster' films are particularly popular with college students and dialogues from these films are used in everyday conversations with friends; when combined with the right kind of accessories (such as motorbikes and mobile phones) this not only becomes a style statement but an indicator of belonging to a youth sub-culture (WHO, 2003).

Among efforts to study the influence of the visual media on sexual behaviour is a study of 300 school girls in Pune which found a strong correlation between their TV watching habits and involvement with boys (Joshi, 2005). Other studies have reported that adolescents "select" songs and speaking styles from films and TV for use as "scripts" in heterosexual interactions (Sodhi, Verma and Schensul, 2004; Belaku Trust, 2004).

The influence of tobacco portrayals in Indian films on young people has also been a subject of recent study. For example, a survey of young people under 18 conducted by BBS indicated that mainstream films wielded a considerable influence on young people and increased their receptivity to tobacco use (Goswami and Kashyap, 2006). These findings are in agreement with the global evidence cited above as also with those of a 2003 WHO study on the influence of tobacco use in the Indian media on youth (WHO, 2003).

More recently, data from a global youth tobacco survey covering 13-15 year olds from 23 states in India found that tobacco advertising was highly correlated with smoking behavior (Shah et al., 2008). A cross-sectional survey on tobacco use among pre-university students in Bangalore city found that nearly one out of every five male students (18\%) and about one out of every 20 female students $(6 \%)$ reported wanting to use tobacco after watching movie/TV stars using it on screen; combined with peer pressure, films and TV were seen to be a powerful influence on smoking behaviors (Bhojani, 2009).

The link between media violence and subsequent aggressive behaviour was demonstrated in a study conducted in ten government schools by the Department of Pediatrics, PGI Medical College, Chandigarh. The study noted that among 15,000 students, those "who were perpetrators (of violence) were the ones who enjoyed seeing more action and violence-oriented programmes on the television and in movies and for a longer duration of time." (The Tribune, 18 March 2003),

These qualitative studies highlight the need to understand not only young people's use of various types of media but also the interaction between media and young people and the pathways through which the former exerts its influence. 


\section{Study setting}

The study locale was Kanakapura, a taluk headquarters town in the newly formed Ramanagara district in south Karnataka, about $60 \mathrm{~km}$ from Bangalore city. The town has a population of 47,060 and an average literacy rate of $66 \%$, close to the state average of $66.6 \%$ and slightly higher than the national average of $64.8 \%$ (Office of the Registrar General and Census Commissioner, 2001). The main occupation of the people is agriculture though the taluk is known for its silk production and granite quarries. In terms of facilities, Kanakapura has one government hospital and five colleges, including just one college offering graduate courses and three government-aided ones offering preuniversity and job-oriented courses. As a result, a large number of students travel from the surrounding villages to Kanakapura every day to attend high school and college.

The study was conducted in the three government-aided colleges namely, a Rural PreUniversity (PU) and Degree College (Rural College), a Municipal Pre-University (PU) and Job-Oriented Course (JOC) College (Municipal College), and a Government Industrial Training Institute (ITI). The colleges offered different courses of study. While the Rural College offered academic courses, and the ITI offered job-oriented courses, the Municipal College offered both academic and job-oriented courses. Academic courses included science, the humanities and commerce; job-oriented courses included sericulture, bookkeeping, plumbing, electrical work and masonry.

The colleges also differed in terms of their environment, student strength and studentteacher relations. The Rural College had the greatest student strength - about 5,000 compared to about 500 in the Municipal College and 300 in the ITI. The Rural College and the PUC section of the Municipal College had equal numbers of male and female students; in contrast, the JOCs were predominantly male -15 girls in the ITI and 11 girls among 71 students in the Municipal JOC. Observations made during study hours indicated that discipline in terms of class attendance and behaviour on campus was rather lax in the Rural College, and that it had a history of frequent clashes (requiring police intervention) between student groups. Study participants of the Rural College also expressed fewer concerns about "being caught" interacting with a member of the opposite sex and shared instances of quarrels among male students over relationships with girls. In contrast, the Municipal College and the ITI had a regimented environment with little leisure time and closely supervised student-teacher relations. Moreover, interaction between boys and girls was strictly monitored and actively discouraged. For example, as a student of the Municipal College reported, "If teachers see a boy and a girl talking in the corridor, they shout at them and threaten to report it to their parents." Likewise, a young man from the ITI complained, "As it is there are so few girls. And even if we talk to them about studies, our teacher gets angry and says, 'Is this why you come to college?',

In terms of academic performance, in all three colleges, more than $50 \%$ of the students had passed the most recent examination. However, a much larger proportion of students in job-oriented courses than in academic courses reported that they had passed the most recent examination for which they had appeared (80-92\% versus 60-67\%). 


\section{Methodology}

The study used a mixed method design consisting of a qualitative data gathering phase and a survey phase. The qualitative phase, extending over a year from August 2005 to July 2006, preceded the cross-sectional survey conducted in October-November 2006; its insights informed the content of the survey.

\section{The qualitative phase}

Participants for the qualitative phase were recruited from all the first and second year classes of the selected colleges. The research team visited the classes, introduced the study, and invited students who were interested in joining the study to meet the team at an appointed place, during the lunch break. Students who gave their written consent were enrolled for the qualitative phase of the study. Table 1 gives a distribution of the 120 students thus enrolled by the type of study course they attended.

\section{Table 1}

Participants enrolled for the qualitative phase by type of study course

\begin{tabular}{|l|c|c|c|}
\hline & Academic courses & Job-oriented courses & Total \\
\hline Young men & 30 & 31 & 61 \\
\hline Young women & 44 & 15 & 59 \\
Total & 74 & 46 & 120 \\
\hline
\end{tabular}

The research team met the participants at their convenience, in the college campus, to collect qualitative information. Table 2 presents the number of young men and young women who participated in the various data gathering exercises of the qualitative phase.

Data gathering for the qualitative phase began with a free listing exercise whereby participants identified the most salient and popular films that were playing in the local theatres at the time of the study. This was followed by pile sorting to establish the criteria used by them to categorize films, and a third exercise in which they rated the identified films by thematic content.

The research team viewed the identified films and selected scenes/clips for focus group discussions (FGDs). Twelve FGDs were held, six each for young men and young women, with 8-9 participants per FGD. Participants watched the selected clips and discussed their interpretations of and opinions about it in terms of what they felt was appropriate/ inappropriate, who they felt was right or not right, how realistic/unrealistic the situation was and so on. These discussions were largely unstructured and helped to understand how young people interpret situations from films. 
Two important areas informed by the qualitative phase were explored in the quantitative survey. One, the survey used four film clips selected on the basis of FGD outcomes, that is, the extent to which the clips succeeded in generating discussion on interpretations of gender relations and sexual and reproductive health matters. Second, the FGDs identified friends and the family as two other major influences in young people's lives. Hence, along with the media (films/TV), we explored the influence of friends and the family on selected behaviours of participants.

In addition to the exercises listed in Table 2, the research team recruited 19 male and 16 female participants who volunteered to participate in in-depth interviews, to gather information on their media use patterns and preferences, and the effect of films/TV, friends and the family on young people's behaviour.

\section{Table 2}

Number of young men and women participating in the qualitative study by method of data collection

\begin{tabular}{l|c|c|} 
& Young men & Young women \\
\hline Free listing exercise & 51 & 58 \\
Pile sorting exercise & 48 & 37 \\
Rating exercise & 61 & 47 \\
Focus Group Discussions (FGDs) & 6 FGDs with an average & 6 FGDs with an average \\
of 8-9 participants each & of 8-9 participants each \\
In-depth interviews & 19 & 16
\end{tabular}

\section{The survey}

Classes offering various courses were selected from the three colleges by stratified random sampling. Students from the selected classes were invited to participate in the survey. Two days prior to the survey, parental consent forms were distributed to students of PU and ITI courses. Parents who had any reservations about their ward's participation in the survey were required to sign and return the form; else their consent was assumed. Students of degree courses gave their own written consent.

Self-administered questionnaires were fielded on days convenient to both teachers and participants. Male and female students from each class sat in separate rooms to complete the questionnaire, prior to which members of the research team briefed them about the purpose and significance of the study, in general, and the survey, in particular. They were also told that in order to protect their confidentiality, no names were required. The questionnaire took about an hour and a half to complete.

Out of a total of 1,173 young men and 608 young women who were enrolled in the selected classes, 841 young men and 514 young women filled out the survey questionnaire. This gave a response rate of $72 \%$ for young men and $84 \%$ for young women, a difference attributed by the teachers to variations in daily attendance and chronic absenteeism, particularly among male students. Five married respondents - two 
males and three females-were excluded from the sample. Hence, data collected from a sample of 839 young men and 511 young women were analyzed. The limited enrolment of young women in the job-oriented courses was reflected in the study sample: just $11 \%$ of the female participants were from the JOC category compared to $89 \%$ from the academic category; the corresponding percentages among young men were 44 and 56).

Survey data of respondents included the following information:

1) Background information: Age, type of college, education and occupation of parents, household economic status and restrictions imposed on the respondent by his/her family.

2) Media use and interpretation

a) Exposure to films: Number of films and number of hours of TV watched

b) Preferences in films and TV programmes

c) Responses to selected film clips: Four film clips were screened. Each film clip was accompanied by a set of closed-ended questions which respondents were expected to answer before the next clip was screened. The film clips portrayed different conflict situations with a woman as the central character, each woman dealing with the situation in a different way. For the purpose of this report, responses to only one of the film clips have been presented in order to illustrate how young people interpret a conflict situation in films. The clip, from the film "Manemagalu", portrays a young, traditionally dressed, unmarried woman being harassed in public by a man; the woman retaliates by slapping the man.

3) Peer network: Number and gender of friends, and activities in which the respondent participated, out of a total of six given activities, with friends of the same and opposite sex.

4) Gender role attitudes: Whether or not the respondent held inegalitarian gender role attitudes was measured in terms of the extent to which the respondent agreed to stereotypical notions of masculinity and femininity. Male and female respondents were asked to indicate the extent of their agreement, on a three-point scale (does not agree, agrees somewhat, agrees fully), to a set of stereotypic and non-stereotypic statements about "a real man" and "a respectable woman", respectively. Factor analyses of statements revealed one strong factor containing nine items for men and eight items for women, which were added up to create an index of masculinity and femininity, respectively. The highest possible individual score on these indices was 18 and 16, respectively, if the respondent agreed with all the items in the index.

The nine items included in the masculinity index were: 'Real men are tall and have a strong body'; 'If a man has more number of girlfriends his status among his peers will increase'; 'A real man beats up a person who has tried to be friendly with his lover/girlfriend'; 'A boy who has a gang is a leader'; 'Boys who smoke attract girls'; 'Boys have to drink and smoke with friends if they have to remain in the group'; 'It is difficult for a man to control his sexual desires'; 'A real man, though married, has relationships outside of marriage'; and 'A real man does not lose control even if he drinks a lot'. 
Items included in the femininity index included the following: 'Respectable girls do not wear clothes that are revealing'; 'Large breasts are attractive'; 'Respectable girls will not laugh loudly or talk too much'; 'Respectable girls will not behave closely with boys - going to films, restaurants'; 'Respectable girls will not have information about sex'; 'If a boy loves a girl she should love him even if she does not feel that way'; 'A woman who undergoes rape loses her purity/chastity'; and 'A respectable woman does not leave her husband's house even if he is ill-treating (beating and abusing) her'.

5) Individual behaviours: Selected respondent behaviours prevalent at the time of the survey were sought, including whether the respondent:

a) Was involved in class-related activities in terms of academic performance and attendance

b) Engaged in teasing the opposite sex

c) Was involved in a love relationship

d) Engaged in violence

e) Engaged in sexual activities including sexual intercourse

f) Smoked

g) Drank alcohol

6) Selected youth sub-culture-related behaviours-recent changes in youth behaviours and leading influences: Respondents were asked if they engaged in a set of eleven behaviours associated with young people's sub-culture and which are expected to be affected by films/TV, friends and the family. As informed by the qualitative phase, in addition to media influence, we studied the influence of friends and the family on these behaviours. The eleven behaviours comprised:

- Change in: hairstyle, dressing style, mannerisms (such as walking, laughing, running one's hand through the hair and so on), and style of talking (four behaviours);

- $\quad$ Teasing: using film dialogues to tease; using film songs to tease; falling in love or involvement in a romantic relationship; and patao-ing (persuading/ winning over or developing a friendship with someone from the opposite sex (five behaviours), and

- $\quad$ Smoking and drinking (two behaviours).

Four of these behaviours - teasing, being/falling in love, smoking and drinking - were probed both with regard to behaviours prevalent at the time of the survey and behaviours likely to have been adopted recently, influenced by the media, friends and the family.

Qualitative information collected during the FGDs was translated from Kannada to English, entered in Atlas/ti version 4.0 and analyzed by theme, separately for young men and young women. Survey data were analyzed using SPSS version 11.5. 


\section{Profile of respondents}

Most of the respondents lived at home with their families (93\% of both young men and women) and sizable proportions commuted to college from nearby villages ( $87 \%$ of young men and $82 \%$ of young women).

\section{Background characteristics}

A profile of the respondents by selected background characteristics indicates significant gender differences (Table 3). Compared to young men, young women were, on an average, a year younger and more likely to belong to a relatively higher socio-economic status; they also reported somewhat higher parental education and, as expected, more family restrictions. Young men, on the other hand, were significantly more likely to get a higher monthly allowance than young women.

\section{Table 3}

Percentage of respondents by selected background characteristics

\begin{tabular}{|c|c|c|c|}
\hline Characteristics & $\begin{array}{l}\text { Young men } \\
(\mathrm{N}=\mathbf{8 3 9})\end{array}$ & $\begin{array}{l}\text { Young women } \\
(\mathbf{N}=\mathbf{5 1 1})\end{array}$ & p values \\
\hline Mean age (years) & 18.1 & $17.2^{* * *}$ & .000 \\
\hline Family background & & & \\
\hline $\begin{array}{l}\text { Ownership of consumer goods (more } \\
\text { than } 6 \text { of } 12 \text { items) }\end{array}$ & 25.0 & $29.8^{*}$ & .021 \\
\hline $\begin{array}{l}\text { Faces family restrictions (more than } 5 \\
\text { of } 8 \text { restrictions) }\end{array}$ & 23.2 & $33.7^{* * *}$ & .000 \\
\hline $\begin{array}{l}\text { Father's educational attainment: } \\
\text { Completed Class } 4 \text { or higher }\end{array}$ & 58.3 & $64.8^{* * *}$ & .000 \\
\hline Mother's educational attainment: & 406 & $490 * * *$ & 000 \\
\hline $\begin{array}{l}\text { Receives more than Rs. } 150 \text { pocket } \\
\text { money per month }\end{array}$ & 27.6 & $10.8^{* *}$ & .000 \\
\hline Academic-related & & & \\
\hline $\begin{array}{l}\text { Obtained distinction marks in the most } \\
\text { recent examination }\end{array}$ & 51.5 & $38.9^{* * *}$ & .000 \\
\hline $\begin{array}{l}\text { Attended class almost every day } \\
\text { Peer-related }\end{array}$ & 39.4 & $54.4^{* * *}$ & .000 \\
\hline $\begin{array}{l}\text { Has friends of the opposite sex } \\
\text { Mean number of activities in which the } \\
\text { respondent engaged (from a total of } \\
\text { 6) with friends of the same sex }\end{array}$ & 75.3 & $58.1 * * *$ & .000 \\
\hline $\begin{array}{l}\text { Mean number of activities in which the } \\
\text { respondent engaged (from a total of } \\
\text { 6) with friends of the opposite sex }\end{array}$ & 1.6 & $0.6 * * *$ & .000 \\
\hline
\end{tabular}

${ }_{p}<<=.050 ; * * p<=.010 ; * * * p<=.001$ 
More than half of the young women compared to two-fifths of the young men (54\% versus $39 \%$ ) reported attending classes regularly though the reverse was true of academic performance with more young men than young women reporting better performance in examinations ( $52 \%$ versus $39 \%$ obtained distinction marks). Young men were also significantly more likely than young women to report having friends of the opposite sex ( $75 \%$ versus $58 \%$ ) and engaging in a larger number of activities with friends of the same as well as opposite sex.

\section{Individual behaviours}

Table 4 presents the percentages of respondents by their reported individual behaviours. As seen in the table, significantly larger proportions of young men than young women reported teasing those from the opposite sex, being in love, and engaging in sexual intercourse; young men were also more likely than young women to smoke, drink alcohol, and engage in violence.

\section{Table 4}

Percentage of respondents by individual behaviours

\begin{tabular}{l|c|c|}
\hline Individual behaviours & $\begin{array}{c}\text { Young men } \\
(\mathbf{N}=\mathbf{8 3 9})\end{array}$ & $\begin{array}{c}\text { Young women } \\
(\mathbf{N}=\mathbf{5 1 1})\end{array}$ \\
\hline Teases those from the opposite sex & 53.8 & $30.4^{* * *}$ \\
Currently in love & 59.4 & $22.0^{* * *}$ \\
Has engaged in sexual intercourse & 34.2 & $4.1 * * *$ \\
Smokes & 23.3 & $0.8^{* * *}$ \\
Drinks alcohol & 15.1 & $1.2^{* * *}$ \\
Has engaged in violence & 29.3 & $19.1 * * *$ \\
\hline
\end{tabular}

$* * * p<=.001$

\section{Teasing}

Findings not only showed that teasing the opposite sex was widespread among both young men and women (Table 4) but indicated that appreciable proportions who were not themselves engaged in teasing, enjoyed watching their friends doing so $(25 \%$ and $20 \%$, respectively; not shown in table). Notably, significant gender differences were apparent in the kinds of teasing behaviours in which young men and women were engaged, who they teased and along with whom. For instance, considerably more young men than young women reported teasing when alone/on their own (36\% versus $8 \%$ ) or teasing an unknown person of the opposite sex (56\% versus 12\%) (not shown in table).

Qualitative findings suggest, moreover, that teasing initiated by young women was very different from that in which young men were engaged. Young women largely reported teasing young men with whom they were acquainted; mainly by passing comments on the clothes and appearance of young men and calling young men by their various names. Young women's teasing was, however, more likely to reflect friendly interaction: 
"I am friendly with these boys. When I need their help I take their notes. I tease them and call them by their nicknames. I am informal and address them in the singular (verb) tense signifying familiarity (ekavachana). One of our friends, tried to take scope (show off) in front of some girls by jumping from the top of the steps, and fell and sprained his leg. Now he is not able to walk properly. The other day, he was playing cricket and I told him, "Kunta (lame one), why are you playing cricket? If you need help in running, tell us, we will help you." (Young woman, $2^{\text {nd }}$ year BA, in-depth interview)

In contrast, teasing among young men comprised behaviours that were clearly harassment such as touching persons of the opposite sex in crowded places (26\%), following and stalking them (27\%) and singing film songs to make fun of them (53\%); such behaviours were seldom reported by young women. Survey findings revealed that more than threefourths of the young men (77\%) who engaged in teasing reported doing so along with their male peers. Friends seemed to provide the safety of numbers and even those who were not actively involved in teasing for fear of being found out by their parents, derived vicarious pleasure through their friends' teasing activities:

"If we see a new girl, we say, "What is this, I say. We are living in Kanakapura but we have not seen you. Where had you hidden yourself?" In our friends circle, one of our friends misbehaves with girls (is 'porki'). When he sees girls coming, he passes between them and says whatever comes to his mind. He is not afraid. I don't tease much because I am scared that someone may see me doing so and inform my father." (Young man, $2^{\text {nd }}$ year ITI, in-depth interview)

Young men's reasons for teasing girls ranged from wanting to draw their attention, to trying to make friends with them (win them over) and, if spurned, to teach them a lesson:

"We tease those girls who take scope (show off)—wear pants, make-up, think they are very beautiful (tripura sundari). There are some girls who don't talk to us even when we talk to them and look down upon us (treat us keelaagi). If a girl is wearing lipstick, we shout loudly, "Apply on my lips too." We do this because we want girls to talk to us...." (Young man, $2^{\text {nd }}$ Year BCom, in-depth interview).

Narratives of young women highlighted the extent to which they had experienced the teasing about which young men had reported. Several suggested that they regulated their interactions with young men. They reported that they were reserved in their interactions, refrained from smiling or giggling when a boy teased them, speaking little and limiting interactions with males only to certain kinds of activities. They feared that if they appeared aloof, they would be perceived as being 'arrogant' and in need of being 'taught a lesson'. For example:

"With boys I am very decent and strict. I don't laugh unnecessarily... In college ground, boys stand around in groups. And our classmates are also with them. I don't talk to them then because if I go and talk to them, then other boys will also start talking to me. And I am not acquainted with them and I don't know what kind of boys they are." (Female, $2^{\text {nd }}$ year JOC, in-depth interview) 
"My friend, , asks why I should make friends with these boys when I don't like them. But I am scared. This college is not ok. When I am in college, I may scold them. But when I am alone, what is the guarantee that they will not harass and tease me? I have seen boys who have done that. It is better to make friends with them. Then we will not have any problems." (Young woman, $1^{\text {st }}$ year BA, in-depth interview)

\section{Being in love}

Almost three-fifths of the young men and one-fifth of the young women reported being in love at the time of the survey, about half of them ( $47 \%$ of both young men and young women who reported so) with a classmate (not shown in table). As expected, young women were considerably less likely to have communicated their romantic interest than young men (19\% versus $32 \%)$; others had communicated so mainly by talking to the person directly $(49 \%)$ and seeking the help of friends (25-30\%), while one-third of the young men $(25-30 \%)$ reported stalking and teasing the girl to indicate their romantic interest, a behaviour typical of the 'hero' in romantic films.

Even though young women reported being in love, they were afraid of pursuing the relationship, fearing rejection as well as being found out by their family:

"I like a boy in PUC $2^{\text {nd }}$ year.... his name is He is super. I saw him for the first time when he came to my classroom to meet someone. After that, I felt like seeing him again and again. I would make excuses to go past his class and see him. Now, both of us smile at each other. I want to tell him that I like him. But I feel very scared-what if he says he does not feel the same way?" (Young woman, $1^{\text {st }}$ year PUC, in-depth interview)

"There is a boy in my college who likes me very much. I have not told him about my feelings yet.... He is a very good boy. I am in love with him now. But I am scared to say anything because of my brother. If he finds out I will be in trouble." (Young woman, $1^{\text {st }}$ year JOC, in-depth interview)

Young men also expressed reluctance in declaring their feelings:

"Till now I have not told her anything. She has also not said anything. But I know she loves me because of the way she talks to me-she talks to me very 'closely'. She does not talk to other boys like that. She does not get scared if other boys are with me; even then she talks to me...." (Young man, $2^{\text {nd }}$ year JOC, in-depth interview)

Yet, young men seemed to be more persistent even after being refused by the girl as the following narrative illustrates:

"First I proposed to her. I told her that I love her and want to marry her. But she said she doesn't like me. Later, I came to know that she is afraid of her family. One day I met her and told her, 'I am not the kind of boy who makes love promises and 
runs away or gets scared of the girl's family. My parents have told me to marry the girl of my choice. When you come to school you will have to tell me your decision.' The next day she met me and said, 'I like you, but I am afraid. Let us not meet like this on the roadside because if someone sees us and informs my family, they will not allow me to go to school." (Young man, $1^{\text {st }}$ year PUC, in-depth interview)

\section{Engaging in sex}

Survey findings revealed that a considerably larger proportion of young men than young women (34\% versus $4 \%$ ) reported engaging in sexual intercourse (Table 4). In in-depth interviews, however, only one young woman reported some form of sexual intimacy with her boyfriend, a neighbour, saying that they had kissed each other and she was worried that the relationship may get more intimate:

"We hold hands and sometime he kisses me. Nobody knows this. I don't like to be kissed... I told him this... but he said he cannot control... One day, his friend told me that he (boyfriend) has started drinking heavily because he is not able to sleep with me. When I asked my boyfriend, he said that this fellow is a trouble-maker and I should not listen to him... But I am worried because I go and sleepover in his house; his sister and mother are very close to me. I am scared something might happen... but he says, 'Don't you have faith in me?'” (Young woman, $1^{\text {st }}$ year PUC, in-depth interview)

Speaking about his physical intimacy with his girlfriend, a young man said that his girlfriend had refused to have sex with him despite explaining to her that condom use would protect her against pregnancy:

"Till now we have not had sex. I called her three to four times. She refused. I told her about 'Nirodh'... I said if I wear it and we have sex, she will not get pregnant... there will be no problem...but she did not agree. She is very scared." (Young man, $1^{\text {st }}$ year PUC, in-depth interview)

Young men thus, not only discussed sexually intimate behaviours with girlfriends but also sexual intercourse with sex workers, as narrated by a young man who visited a sex worker with his friends:

"First we fixed the rate with the woman. A minimum of Rs.250/-. We were three of us. We went in one by one. We gave a 50-rupee tip to the lodge boy to make sure there is no trouble (tondare). That time I used a condom-Masti." (Young man, $3^{\text {rd }}$ year BA, in-depth interview)

\section{Cigarette smoking and alcohol consumption}

Cigarette smoking and alcohol consumption were not probed in qualitative phases of the study. In the survey, almost one out of every five young men reported that they smoked cigarettes and fewer $(15 \%)$ that they engaged in drinking alcohol. Very few young women reported either behaviour ( $1 \%$ each), again a possible consequence of their conforming to family expectations and social norms. 


\section{Violence}

As seen in Table 4, nearly one-third of young men and one-fifth of young women reported that they had engaged in violence defined as having beaten up someone in the three months prior to the survey. We caution readers that since the question was general and open-ended, it may have included acts of violence within the home as well as outside it, and against siblings or other family members as well as others; this may explain the relatively large proportion of young women reporting having engaged in violence.

\section{Gender role attitudes}

Survey findings also highlighted differences in gender role attitudes of respondents. As seen in Table 5, more than twice as many young men as young women scored 12 or more on the masculinity index, indicating that young men were far more likely than young women to hold stereotypical and unequal gender role attitudes. Surprisingly, no such difference was observed on the femininity index where nearly $30 \%$ of young men and $25 \%$ of young women were in the high score category suggestive of traditional attitudes towards women's roles.

\section{Table 5}

Percentage of young men and young women reporting traditional notions of masculinity and femininity, as measured by the masculinity and femininity indexes

\begin{tabular}{|l|c|c|} 
& $\begin{array}{c}\text { Young men } \\
(\mathbf{N}=\mathbf{8 3 9})\end{array}$ & $\begin{array}{c}\text { Young women } \\
(\mathbf{N}=\mathbf{5 1 1})\end{array}$ \\
\hline $\begin{array}{l}\text { Participants scoring } 12 \text { or more on masculinity } \\
\text { index with a total score of } 18\end{array}$ & 17.6 & $8.0^{* *}$ \\
$\begin{array}{l}\text { Students scoring } 12 \text { or more on femininity index } \\
\text { with a total score of } 16\end{array}$ & 29.7 & 25.6 \\
\hline
\end{tabular}

$* * p<=.010$

The indexes have been defined in the section on the Survey.

A comparison of the average scores of young men and women showed that both reported lower scores on the masculinity index ( 7.58 and 5.77, respectively) as compared to the femininity index (9.51 and 8.78 , respectively), suggesting that attitudes related to women were much more stereotypical and inflexible as compared to those towards men.

\section{Media use patterns}

Table 6 presents the quantum of exposure of young men and women to films and TV. Findings indicate that young men's exposure to mainstream films and TV was significantly greater than that of young women (17 versus 11 films per month). However, there was no significant difference in their exposure to TV. 
Table 6

Exposure of respondents to mainstream films and TV

\begin{tabular}{|l|c|c|} 
& $\begin{array}{c}\text { Young men } \\
(\mathbf{N}=\mathbf{8 3 9})\end{array}$ & $\begin{array}{c}\text { Young women } \\
(\mathbf{N}=\mathbf{5 1 1})\end{array}$ \\
\hline Average number of films watched per month & 17.03 & $11.43 * * *$ \\
\hline Average number of hours of TV watched per day & 2.46 & 2.58 \\
\hline
\end{tabular}

$* * * p<=.001$

\section{Film and TV preferences}

As seen in Table 7, films with love stories and family themes were most watched by both young men and women. Between the two themes, however, significantly more young men than young women reported a preference for love stories $(63 \%$ versus $47 \%)$ while significantly more young women than young men preferred storylines revolving around family themes such as parental love and brother-sister relationship (78\% versus $52 \%$ ).

\section{Table 7}

Percentage of respondents by preference for mainstream films and TV

\begin{tabular}{l|c|c|} 
& $\begin{array}{c}\text { Young men } \\
(\mathbf{N = 8 3 9})\end{array}$ & $\begin{array}{c}\text { Young women } \\
(\mathbf{N}=511)\end{array}$ \\
\hline Films watched most often & 63.2 & $46.6^{* * *}$ \\
Films with love stories & 52.4 & $77.8^{* * *}$ \\
\hline Films on family themes & 48.9 & $18.8^{* * *}$ \\
Films with rowdyism & 26.2 & $2.2 * * *$ \\
Films with sexy scenes & & 95.7 \\
TV programmes watched most often & 85.8 & 21.2 \\
\hline Daily soaps & 44.2 & \\
Comedy shows & &
\end{tabular}

$* * * p<=.001$

Column totals may exceed $100 \%$ due to multiple responses.

In-depth interviews echoed these findings. For example, a young man from an academic course explained what he looked for in films with love stories:

"I watch love films with good music and dialogue. The location and lyrics should be good too. Most importantly, I like stories in which the boy and girl fall in love, face problems from others, face a lot of hardship but overcome all the difficulties (kashtagalu) and come together. I watch such films more than I do others." (Young man, $3^{\text {rd }}$ year BA, in-depth interview) 
Another young man described how certain social values got reiterated through films with a family theme:

"In one of his films Doddanna (a comedy/ character actor) quotes a proverb (gaade maatu): 'Neeru iruvaregu bhavi, Tayi irovaregu tavaru' (Only till the time there is water will a well be called a well; only till the mother is alive will a girl's natal home be called her own). My sister is married. When she came home the other day my mother said: you will come to this house till the time that I am alive. After that how can you come? So I feel these films really show things that are real." (Young man, $2^{\text {nd }}$ Year BA, in-depth interview).

Almost half of the young women reported a preference for films with love stories (Table 7). They were, however, careful to indicate what they liked about such films and what they did not as the following words of a young woman indicate:

"I like to watch love films also. Like in the film 'Akash'. In this film, initially they are friends. Later, they become lovers. I don't like films in which the clothes (worn by girls) are not proper-like girls wearing short dresses above the knees or wearing something like a bra on top. Such clothes have a lot of effect (prabhava) on boys; they will start imagining all girls in such dresses only." (Young woman, $1^{\text {st }}$ year PUC, in-depth interview)

As seen in Table 7, the majority of young women (78\%) expressed their preference for family-based films. In-depth interviews suggest that young women tended to relate to much of the content. For example, a young woman from a job-oriented course shared what she sought from films with family themes thus:

"I like sentimental films like 'Yajamana', for example. In these films, love, faith and relationships are emphasized. Money may come and go... but love, faith and relationships are permanent (shashawatat). This kind of film remains in my mind. These films are based on incidents that are happening in our lives, in our joint families...." (Young woman, $3^{\text {rd }}$ year BA, in-depth interview)

Apart from preferring family-based films for their portrayal of family values and bonding, young women not only said that the real-life, day-to-day incidents in such films served as lessons in harmonious living but hoped that parents/brothers who also watched them would learn to trust and not misunderstand their children/sisters, as the following quotes illustrate:

"I like sentimental films ...parents, brother/sister... I feel that seeing such films will make parents realize the mistakes they make...for example, in the film 'Suryavansha', the father opposes his son. Later, he comes to know his son's good nature. In the end, they all come together. In other sentimental films about brother/ sister love such as 'Anna Tangi' and 'Tavrige ba Tangi', the relationship shown is really good. But brothers are not like those shown in films. For example, in the film 'Tavarige ba Tangi', the girl's brother does not misunderstand her when he sees her talking to boys ...I would like to have a brother like that...." (Young woman, $2^{\text {nd }}$ year JOC, in-depth interview) 
"I like comedy and sentimental films. Comedy helps us forget our worries.

Sentimental films show the current situation in society and give us examples of how to sort out family misunderstandings, how to co-operate and live together...." (Young woman, $2^{\text {nd }}$ year BA, in-depth interview)

Another young man from a degree course, however, held a contrary view, labeling such films as 'over-sentimental':

"I don't like to watch films that are over-sentimental. We also end up crying like in the film 'Tayilada Tabbali'. Why should we pay and cry? That's why I avoid such films." (Young man, $2^{\text {nd }}$ year BCom, in-depth interview)

Table 7 shows further differences between the preferences of young men and women. For example, significant proportions of young men compared to young women reported a preference for films depicting sex scenes (49\% versus 19\%) and rowdyism (26\% versus $2 \%$ ). A young man from the ITI explained his liking for violent films (rowdyism) thus:

"I like violent films in which there is a fight for a good cause and they win. In such films, those who behave arrogantly are taught a lesson... Nowadays, rich people and politicians get away with anything...Even if they make a mistake, nobody can question them...If we fight lawfully, they have the power to change the law itself. They convert truth into lies and lies into truth. The only way to teach such people a lesson is to fight...I like films where there is a fight against injustice." (Young man, $2^{\text {nd }}$ year ITI, in-depth interview)

Reported preferences for TV programmes were somewhat similar in that an overwhelming majority of both young men and women reported watching daily soaps on TV (86\% and $96 \%$, respectively); followed by comedy shows though twice as many young men as young women so reported ( $44 \%$ and $21 \%$, respectively).

These qualitative findings suggest that young men and women were pre-occupied with different issues which, in turn, guided the kinds of films they preferred and what they sought from them. While young men seemed to look for entertainment and romance as much as for larger social messages that were not immediate to their own life situations, young women seemed to identify more closely with themes depicted in the media and seek ideas that they could apply to their own life. This finding seems to support the "circular model" proposed by Steele which recognizes young people as "active audiences" who judge media content "in terms of credibility as well as suitability (of use) for their specific situations and daily life experiences" (Steele, 1999).

\section{Context of exposure to mainstream films}

Table 8 presents percentages of young men and women by the venue where they usually viewed films and the person/s with whom they did so. 
Table 8

Percentage of respondents by venue and person/s with whom they watched films

\begin{tabular}{l|c|c|} 
& $\begin{array}{c}\text { Young men } \\
(\mathbf{N = 8 3 9})\end{array}$ & $\begin{array}{r}\text { Young women } \\
(\mathbf{N}=499)\end{array}$ \\
\hline Watch films usually & 41.4 & $9.2^{* * *}$ \\
In a theatre & 60.5 & $81.7 * * *$ \\
At home, on TV & 18.2 & $33.7 * * *$ \\
At home, on CD & 9.2 & $4.6^{* * *}$ \\
At friends' homes, on CD & & $1.8^{* * *}$ \\
Watch films usually with & 22.3 & 25.4 \\
\hline No one (Alone) & 23.2 & $4.6^{* * *}$ \\
Friends of the same sex & 36.7 & $4.8^{* * *}$ \\
Both male and female friends & 10.4 & $62.1 * * *$ \\
\hline Girlfriend/Boyfriend & 17.6 & \\
\hline Family & &
\end{tabular}

$* * * p<=.001$

Column totals may exceed $100 \%$ due to multiple responses.

$† 12$ young women did not respond to this question and are excluded.

Findings highlight that young women not only faced more constraints on mobility than did young men, but were also more likely to encounter restrictions in the choice of the person/s with whom they could watch films. Unlike young men who had the freedom to choose both the venue and company for watching films, for young women the setting was limited mainly to their home, and the choice of company to family members or friends of the same sex. For example, although most young men and women viewed films on TV in their own homes $(61 \%$ and $82 \%$, respectively), far more young men than women viewed films in a theatre $(41 \%$ versus $9 \%)$. Moreover, for the majority of young women $(62 \%)$, watching films, whether on TV or CD, was with their family members, and while an equal proportion (one in every four) of young men and women watched films together with their same sex friends, far more young men than women watched films together with their male and female friends $(37 \%$ versus $5 \%)$ and with their opposite sex friend $(10 \%$ versus $5 \%$ ). Clearly, young men were considerably more likely than young women to enjoy the freedom to choose both the venue and the accompanying person/s.

For young men, theatres provided a convenient setting for interacting with girls and for engaging in a host of activities, all of which apparently added to their enjoyment. As a young man explained:

"In the theatre, we first see whether there are any girls or aunties (older women) and sit next to them or behind them. We whistle and scream when there is a sexy scene or if there is any double-meaning dialogue (with sexual innuendo). If the girls protest, we pick a fight with them.... After the film, on our way out of the theatre, we push each other on the girls." (Young man, $3^{\text {rd }}$ year BA, in-depth interview) 
Another young man, from the commerce course, described how he and his friends enjoy films with sexy scenes and even see them repeatedly:

"When we friends go to see a film, we watch how the hero removes the heroine's clothes, and try and see if we can see her breast; whether she is wearing a bra and underwear... We observe all these things. After the film, we discuss what each one of us has observed. If one of us has missed something, we go to see the same film again. In this way, we have seen many films about 5-6 times. In the film 'Akash', in the song, "Neene neene", the heroine's underwear is visible... but one of our friends did not see it. So we went again only to show it to him." (Young man, $3^{\text {rd }}$ year BCom, in-depth interview)

In contrast, qualitative information gathered from many young women brought into focus family restrictions on watching films in a theatre and even on watching certain types of films at home on TV. As one young woman explained:

"I don't go out to watch films. I go out only if my sister takes me. I mostly watch films at home. My family will not allow me to go out to see films. If my brother is at home, I don't watch love films. He doesn't like love films. If there is some such thing on $T V$, he asks me to go inside. One day, my sister and I were watching the film 'Partha' on TV. My brother came in and changed the channel and started watching sports. My sister asked him why he did that, saying that I had not seen the film. He said, 'If she watches such films, she will also learn the same thing. That's why I changed the channel'." (Young woman, $1^{\text {st }}$ year JOC, in-depth interview)

Qualitative findings highlighted the constraints placed on the mobility of young women and on the extent to which they were permitted to mix with young men. Indeed, even when permitted to go a theatre, their parents/family insisted that they go only with other girls:

"My family insists that I go only with girls. They don't allow me to go with boys." (Young woman, $3^{\text {rd }}$ year BA, in-depth interview)

One in ten young women, however, did go to theatres with friends and fewer (5-6\%) reported doing so in large mixed groups of friends but rarely reported going to a theatre with a boyfriend. In fact, a young woman even revealed the ingenious way in which she dealt with constraints placed on her by her parents:

"I watch love and friendship films with friends. But I feel very scared to go to the movies with boys because my father does not like it. So I have made a plan. I ask one of my Muslim friends for her burkha. I wear this whenever I go to a film with boys. Once, I had already seen a film with my sister but I went again to watch it with my friends." (Young woman, $1^{\text {st }}$ year PUC, in-depth interview)

Interestingly, several young women agreed with the restrictions placed on them, arguing that watching films at home on TV was preferable and less likely to cause discomfort. For example: 
"I watch films on TV and in the theatre. I like to watch films at home because there are few people. In the theatre, there are a lot of people around... and today's film heroines wear short dresses... I feel awkward because boys' way of looking is not good; it makes me feel awkward and embarrassed coming out of the theatre." (Young woman, $3^{\text {rd }}$ year BA, in-depth interview)

However, not all women shared this view. In fact, many young women explained that they did not enjoy watching films, particularly love films, at home, because there was no "maja" (fun) watching them without being able to comment on the lead actors:

“... But I don't enjoy watching love story films with the family because when I am with friends, we pass comments on the clothes worn by the hero or the heroine, how they look and so on. But with the family, I cannot do such things. I have to watch the film quietly and that is no 'maja'." (Young woman, $1^{\text {st }}$ year JOC, in-depth interview)

Yet others feared that their parents/elders may suspect them of behaving like the college girls portrayed in the film, or worry that they would be influenced by the portrayals, as the following quotes suggest:

"I don't like to watch love story films with family members. If I watch love stories and love scenes with them, they will think that all college going girls do such things and will begin to suspect me...." (Young woman, $1^{\text {st }}$ year PUC, in-depth interview)

"I don't watch love films with the family because they will think that I may also fall in love in future. In some love films, they show the boy and girl falling in love and eloping because their families do not approve of their marriage. Later, their family members separate the couple. When (our) parents see such films, they get worried; they think that their children will learn such things from films." (Young woman, $1^{\text {st }}$ year PUC, in-depth interview)

Unlike young men then, young women seemed to be much more under the control of their families in terms of what kinds of films they watched, where they watched the film, and with whom. While most young women tended to conform to family expectations, others devised ways to circumvent the restrictions imposed on them. 


\section{Interpretation of situations from films}

As mentioned earlier, the film clip about a conflict situation from "Manemagalu" was screened and followed up by asking the participants a set of open-ended questions to understand how they interpreted a conflict situation in a film.

\section{The film and film clip}

"Manemagalu" is about the travails of a young woman who incurs the wrath of a man because she hits and insults him when he tries to harass her in a public place. The man avenges himself by writing an anonymous note to a rich man she is about to marry informing him that she has leprosy. The rich man humiliates her by compelling her to wash her face just before the wedding to make sure that she has not been hiding leprosy patches under her "make-up". Convinced that she does not have leprosy, he agrees to go ahead with the wedding, but the young woman refuses. However, determined to get married and much against her parents' entreaties, she asks the departing guests at the wedding whether anyone would marry her. A man with a disability stumbles into view. She asks him directly; he agrees to marry her and they get married. The rich man spurned by her and the one she had hit in public get together and decide to teach her a lesson. A series of hardships follow: her parents disown her; she becomes pregnant and has an abortion, and the poultry business set up with her husband is set afire and destroyed. Eventually, the father of one of her two tormentors, who is also the village head, supports her. In a final violent confrontation, he kills his own son and the woman is vindicated.

The scene in the film clip is a pivotal one, to which all the events in the films are linked. It establishes the character of the female lead and all the events in the film follow as a consequence of the young woman's actions depicted in it. The scene starts with a young woman with flowers in her long, plaited hair, dressed in a traditional South Indian halfsari, coming out of a temple after pooja (worship) and giving alms to the beggars outside the temple. A man is hanging around with his friends, watching her. He comments to his friends that she looks like an oasis in a desert. The young woman turns to leave, the man bumps into her, and the coconut and flowers she is carrying fall to the ground. The man apologizes, saying that he wasn't looking. The young woman says it's ok, turns, puts on her chappals (footwear) and is about to leave when he bumps into her a second time. This time, she gets angry, takes her chappal in her hand and hits him across the face. What follows is a fight where the young woman manages to hit him hard enough for him to retreat. She is applauded by her friends and she shouts a parting shot at him, "I am a Kasturi Kannada woman born in Karnataka and have drunk the pure waters of the Cauvery. If you ever again so much as look at a woman, you should remember the beating that this Janaki has given you. Now get lost!"

Table 9 presents the responses of the participants to the questions following the screening of the film clip. Their interpretations of the situation depicted in the clip fell into three distinct groups: perceptions about the young woman's character, interpretations about the 
acceptability of the young woman's act (of hitting the man), and perceptions about the possible consequences of the young woman's act.

\section{Table 9}

Responses of young men and women to questions about the film clip

\begin{tabular}{|c|c|c|}
\hline Response items from the survey & $\begin{array}{c}\% \text { young men } \\
\text { agreeing to the } \\
\text { statement }(\mathrm{N}=\mathbf{8 3 9})\end{array}$ & $\begin{array}{l}\% \text { young women } \\
\text { agreeing to the } \\
\text { statement }(\mathrm{N}=\mathbf{5 1 1})\end{array}$ \\
\hline \multicolumn{3}{|l|}{$\begin{array}{l}\text { Perceptions about the young woman's } \\
\text { character }\end{array}$} \\
\hline She is a traditional young woman & 90.8 & $98.0^{* * *}$ \\
\hline She values her honour & 92.1 & $98.0 * * *$ \\
\hline She is brave & 96.0 & $99.0 * *$ \\
\hline $\begin{array}{l}\text { She is a role model for other young } \\
\text { women }\end{array}$ & 92.0 & $98.0^{* * *}$ \\
\hline $\begin{array}{l}\text { She is a bajari (a derogatory term for } \\
\text { an aggressive woman) }\end{array}$ & 38.0 & 32.4 \\
\hline The young woman is arrogant & 20.2 & $3.2 * * *$ \\
\hline $\begin{array}{l}\text { The young woman should not have hit } \\
\text { him }\end{array}$ & 38.4 & $26.5 * * *$ \\
\hline $\begin{array}{l}\text { Perceptions about the possible } \\
\text { consequences of the young woman's } \\
\text { act in the clip }\end{array}$ & & \\
\hline The boy will seek revenge & 86.6 & $93.7 * * *$ \\
\hline $\begin{array}{l}\text { The young woman will get a bad } \\
\text { reputation }\end{array}$ & 40.0 & 39.1 \\
\hline $\begin{array}{l}\text { The young woman's family will scold } \\
\text { her }\end{array}$ & 51.8 & $46.9^{*}$ \\
\hline This is not possible in real life & 47.0 & $40.5^{*}$ \\
\hline
\end{tabular}

$* p<=.050 ; * * p<=.010 ; * * * p<=.001$

Column totals may exceed $100 \%$ due to multiple responses.

\section{Perceptions about gender roles}

As seen in Table 9, an overwhelming majority of both young men and women approved of the woman's behaviour (92-96\% and $98-99 \%$, respectively), saying that she is a traditional (sampradayastha) young woman who values her honour (maryade); that she is brave (dhiryavante) and a role model for other girls/young women. The clip had previously generated a great deal of animated discussion in the FGDs of both young men and women. 
Young men's support of the girl seemed to stem from the fact that she was a sampradayastha girl as this excerpt from an FGD with young men from the ITI indicates:

R1: What she did was right. She protected her honour (maana).

R6: She looks like she is a traditional girl (sampradayasthalu)....by the clothes she is wearing...

R3: Such girls are liked by good sampradayastha boys.

R1: Because she was a sampradayastha girl, she hit him and protected her maana. If it had been a girl who enjoys and attracts male attention (chengulu), she would have gone and dashed against him herself.

R4: What she did was right because the man deliberately and repeatedly kept on dashing into her.

R5: She is wearing a good (conservative) dress. Her dress is not bad. His way of seeing is bad. If the woman was like the one in the film 'Malla' (a film where the female lead actor is shown wearing short western clothes) and there was a rape scene there, I would have felt like being in the rapist's place myself. I would have done what he did. But in this case, I don't feel like that. Here, I feel like supporting the girl.

(Laughter and some participants tease R5)

Young women's discussions drew similar interpretations. In excerpts from two FGDs, young women raised the issue of appropriate behaviour in a girl from a sampradayastha family: that she should not draw attention, particularly male attention, to herself, should dress in traditional clothes like the girl in the clip did, and should value and protect her honour (maana). Much like the young men, young women also absolved the girl of culpability because she conformed to their notion of a girl from a sampradayastha family as the following excerpt of a young women's FGD illustrates:

R3: He saw a good-looking girl and started to rag her...

R2: It is ok to tease (regisuvudu) but touching is wrong...

R4: She is from a good sampradayastha family. That is why she scolded him, hit him and gave him some advice...

R1: She fought to protect her honour (maana)......If she had kept quiet even after he dashed into her, then he may have spoilt her chastity (sheela).

In another FGD, the women said:

R6: She was dressed correctly and still the man was teasing her; that is why she hit him with her slipper.

R1: (Like the girl in the clip)... We should not encourage (give prothsaha to) them when they tease us. We should not keep looking towards them or giggle when they tease. We should threaten to inform their family members. Or, only say that we will hit you with a slipper. If the girl laughs or giggles, the boy will tend to think that she is in love with him and will continue to tease her.

Notwithstanding the fact that many young men and women supported the young woman for honouring conventions of respectability, more than one-third of the young men and 
women also believed that she was a bajari, a derogatory term for an aggressive women, because she had actually hit a man, an act unbecoming of a sampradayastha girl (Table 9). On the other hand, substantial proportions of both young men and women $(47 \%$ and $41 \%$, respectively) found the portrayal very unrealistic as the following excerpt from an FGD with young men illustrates:

(Observation: Some boys were shaking their heads in disbelief and disapproval and looking away...).

R5: This was too much (over).... No girl hits a boy with her chappal as shown in the clip...

R3: I felt she was unwomanly (gandubeeri) and an aggressive woman (bajari).... She is wrong.

R7: No, I feel that the girl is very courageous (dhiryavante).

R1: I liked the way the boy and girl dashed.....

R7: I think the boy cannot fight at all...he was deliberately dashing into the woman... if such boys love a girl, they don't marry her; ...they cheat her (do mosa).

R4: This clip is really too much (over)... a girl cannot fight a boy like that....

In another FGD, however, a young man expressed a divergent view stating that "dashing into girls" was "common" and that the woman in the clip was over-reacting:

R9: It is quite common to bump into someone (do dikki) like the guy in the clip. In our village fair, I myself have done it three times and the girl did not say or do anything. I then asked her, 'Did you feel bad that I dashed into you?' She said, 'It's ok. I didn't take it seriously.' So, you see, she did not mind me dashing into her. So this is quite common and there is no need to get so angry.

Young women, although less inclined to believe the act to be unrealistic, agreed that retaliating in the way shown in the clip would mean transgressing the norms of a sampradayastha/maryadastha (respectable) woman:

R3: Maryadastha and quiet girls do not do that sort of thing. That is why boys target them and harass them. That is why we should not be quiet all the time....

\section{Interpretations of the acceptability of the woman's act of hitting the man}

A significantly larger proportion of young men compared to young women disapproved of the woman hitting the man ( $38 \%$ versus $27 \%$ ). This was a hotly debated issue among both young men and women, in all the FGDs. In the following excerpt from an FGD with a group of young men from an academic course, one of the participants seems to support the young woman's action while others believe her to be wrong:

R10: If the man makes a mistake and a woman slaps him, it is correct. He should also be punished.

R4: You are forgetting that if a man loses his honour, it will come back. But it is not the same for a woman. She will be called unwomanly (gandubeeri) and society will look down upon her.

27 Films and TV: Viewing patterns and influence on behaviours of college students 
R10: Even if she had not slapped him and tolerated it, and gone away quietly, people would have blamed her saying, 'How come even when he dashed into her she walked away without doing anything?'

R7: If people would have felt that dashing against the girl was wrong, then they themselves would have beaten him up or scolded him. But in this clip they didn't do anything. Why?

R10: She may have got angry because the pooja articles (samaan) fell down. I thought she would tell the bystanders and they would beat him up. But she herself did it. Yeah.... I agree that she should not have hit him herself but got other people to hit the man.

Notably, by the end of the discussion, even the young man who was empathetic to the woman's situation in the clip, eventually conceded that she should not have taken the drastic step of hitting the man herself.

Apart from perceptions that the woman had lost her reputation, young men's narratives also highlighted the notion that a woman hitting a man is an extremely insulting act, an affront to masculinity itself, which few men would tolerate as this excerpt from a young men's FGD indicates:

R8: The girl's friends are clapping when she slaps the guy with her chappal. This is an insult to manhood (gandasthana).

R1: Do you think a man can tolerate such an insult? He can tolerate anything but he cannot tolerate an insult from a woman.

R3: He has been insulted. He has developed hatred (dvesha) towards her. She cannot escape his revenge (avalu bachao aagolla). He may create problems for her; he may rape her, spoil her reputation by spreading malicious rumours (apaprachara).

R4: The girl has insulted him by slapping him, and her friends by clapping and applauding her act. He will not keep quiet.

\section{Perceptions about the possible consequences of the woman's act}

There was wide consensus among both young men and women in the survey $(87 \%$ and $95 \%$, respectively) that the most likely consequence of the woman's act was that the man would seek revenge. This was also voiced in nearly all the FGDs by both young men and women. In one of the FGDs, a young man also shared an incident he had heard in his village:

"I know what can happen if a girl does that. When I was in school, we had a teacher. A rich man teased her, using bad words and she showed him her slipper. She also complained to the police. He then apologized and said he would not do so again. One day, as she was leaving school, he came in someone's car and offered her a lift, saying he was going her way. She went with him. He raped and killed her, and a few days later, her body was found without any clothes on That is why, even if it is the boy's mistake, the girl should go away quietly. If she does not, the boy will take revenge and it is dangerous for the girl." 
The following excerpt from an FGD with young women is illustrative of the concerns young women raised about retaliating against teasing or harassment:

R3: If a girl hits a man like this, will he keep quiet? He will rape her when she is alone...that is why girls keep quiet when boys tease...

R1: Girls are not physically stronger than boys... When boys tease, girls sometimes scold...but even that is rarely done...

R3: Boys' group (gumpu) is big and one should not get involved with them (go to their tante) ... girls should stay away from them.

R1: If we keep quiet when boys tease us; after some time, they will keep quiet, on their own. This has happened to me... when I was in 1st Year BCom, there was a boy who used to tease me... but I did not bother about him and kept quiet. And after a while, he stopped teasing me

R5: If we say or do something when they tease, their anger will increases... they will want to insult us (do avamana) and so develop hatred (dvesha)... In a certain college, a boy teased a girl and she scolded him; the boy retaliated by kissing her in front of everyone... When you hear such incidents, you get scared to take on boys....

In another FGD, a young woman described how actions such as the one shown in the clip could invite a bad reputation:

R5: It is not easy (to protest). The girl will get a bad name. The neighbours will say she is the kind who has no shame, they will call her names-that she is aggressive (bajari), like a man (gandubeeri), and that she has done something shameful; has lost her honour and respect (mooru bittavalu—naachike, maana, maryade). She may even have difficulty getting married if she develops such a reputation. That is why parents scold and instill fear in girls that they should not protest.

In yet another FGD, young women suggested that girls should not only fear retaliation from the boy, but also being blamed or even grounded by their parents and families or made to discontinue their education if they voiced their grievances, and that the best course of action would be silence:

R3: Some girls will not share no matter what happens to them...because they worry that others will suspect them...

R1: They are scared that the boy might retaliate if they complain... so they keep quiet....

R1: Nowadays, if a girl wants to go to college, she has to keep quiet whatever the boys do...

R3: If her family has a good opinion about her, they will support her. Otherwise they will scold her and keep her at home, and get her married as soon as possible.

Thus, for young women a great deal seemed to be at stake. They agreed that they had to remain silent if they did not want to be targeted by men/boys, if they wanted to uphold their reputation of a maryadastha/sampradayastha woman, and if they wanted to continue their education or ensure that they were permitted to engage in activities of their interest outside the home. 
Young men's and women's responses to the film clip, thus, seemed to be conditioned largely by their notions of gender-appropriate behaviour and are in consonance with our earlier finding that gender role attitudes were deeply ingrained in both young men and women. In this case, support for the woman in the clip was largely because she fit the norm of a respectable (maryadastha) woman - one who did not try to attract male attention and actively tried to protect her honour (maryade). However, the act of slapping the man resulted in the woman forfeiting much of that support and being perceived as overly aggressive. Many young men felt that the act of hitting a man was not an act of retaliation against an individual but an affront to men in general (gandasthana or manhood), was inexcusable and likely to result in dire consequences.

While young women were more likely to perceive that the woman was justified in hitting the man, they were worried about the consequences. Given that most young women admitted that sexual harassment in public spaces was common, the worries and dilemmas that young women expressed seemed rooted in their daily experiences. While they supported the girl for being 'respectable' and protecting her honour, and admired her courage (dhirya), they were also worried about retaliation from the man and the extent to which her action might tarnish her respectability.

The film clip seemed to evoke strong responses in both young men and women. Young men reacted strongly because it depicted what they considered to be an extreme reaction from the woman. And it elicited strong reactions from young women because this was an issue they had to negotiate in their daily lives. Both their responses to the clip seemed to reflect the larger socio-cultural norms in society that define appropriate behaviour for women. 


\section{Influence of the media, friends and the family}

As mentioned earlier, findings of the qualitative phase of the study suggested that, in addition to the media (films/TV), friends and the family also have an important bearing on young people's behaviours. Based on this finding, the study explored the influence of the media, as well as the family and friends on eleven selected behaviours (described earlier) associated with young people's sub-culture. Respondents were asked whether they had recently adopted each of the 11 behaviours; those who reported affirmatively were probed about what or who had influenced them to make the change. Specifically, they were asked whether they were influenced by films/TV, friends, the family, and/or anyone else; they could indicate as many options as applicable.

Column 2 of Table 10 and Table 11 presents percentages of young men and women, respectively, who reported behaviour changes. A comparison with percentages who report engaging in four of these behaviours, namely teasing, being in love, smoking and drinking (see Table 4), suggests that for the large majority who reported engaging in these behaviours, the behaviour had been recently adopted, underscoring the fact that sexual behaviours and substance use are likely to be initiated in these ages. Overall, young men were significantly more likely than young women to report changes in each of the eleven behaviours, suggesting that they were better able to adopt a new behaviour than young women who were more likely to be constrained by family and social controls. Further, among the behaviours explored, the largest proportion of young men and women reported recent changes in dressing style and mannerisms (48-76\% of young men and $32-49 \%$ of young women). Notably, large percentages of both young men and women reported 'falling in love' ( $52 \%$ and $29 \%$, respectively); fewer reported the other four heterosexual behaviours (33-39\% and 6-16\%, respectively).

Columns 5-7 of Table 10 and Table 11 present percentages of young men and women, respectively, who attributed the change in behaviour to the influence of the media, peers and the family. Findings show that while the family exercised the least influence on the behaviours explored, media and peer influences differed by gender and the extent of family and social sanctions imposed on young men and women. For example, among young men who had greater mobility and access to films, media influence was most evident and largely affected behaviours related to heterosexual interaction, while among young women bound by social sanctions, peer influences predominated and were held most responsible for changes in dressing style and mannerisms.

\section{Influence of the media (films/TV)}

Among young men who had recently changed any of the eleven behaviours, changes in as many as six were most influenced by the media (reported by 50-62\%) compared to peers or the family $(8-45 \%)$, consistent with their high exposure to films (17 films viewed per month versus 11 by young women; Table 6). 
Column 5 of Table 10 and Table 11 shows the influence of the media (films/TV) on the behaviours explored. Notably, the six behaviours reported to have changed largely due to media influence included all five behaviours related to interaction with the opposite sex (Table 10). Young women, in contrast, reported recent changes in only four of the 11 behaviours largely due to media exposure; nevertheless, as many as three of these concerned heterosexual interaction (43-63\%) (Table 11).

Findings also indicated that though teasing the opposite sex was widespread among both young men and women (Table 4), more young men than young women who currently teased, had initiated the behaviour only recently. Thus, almost three out of every four young men who teased, said that they had adopted the behaviour recently compared to one out of every two young women who currently teased reporting the behaviour as recent. The most obvious influence of the media, however, was seen among young men who had fallen in love-almost nine out of every ten young men who reported to have been in love, had so experienced only recently.

The influence of the media on behaviour changes reported by young men was amply corroborated by in-depth interviews, highlighting that films offer cues that encourage them to tease and pursue girls. As a young man affirmed:

“...Films have given a lot of inspiration... like 'Mahabharat', 'College Hero', 'Love Story', 'Pandu Ranga Vittala' and 'Mandya'. These films tell us about teasing and sex very nicely. In 'Mahabharata', they have described how to tease girls very well..." (Young man, $2^{\text {nd }}$ year JOC, in-depth interview)

Young men's responses also illustrated the central role of films as a source of "scripts" for "patao-ing" (winning over) girls, and in initiating and furthering romantic relationships with them, including how to attract the girl's attention, make her "fall in love" and so on, as the quotes below indicate:

"Films have also encouraged me to love. I really liked the film 'Ninagagi'. In this picture, both are friends; the hero falls in love with the girl but he does not tell her. She also does not guess. I am also in a similar situation. I feel I should also do something that will make the girl love me. In the film, the girl gets engaged to another boy but in the end she comes to know and marries the hero." (Young man, $2^{\text {nd }}$ year JOC, in-depth interview)

'In 'College Hero', they show how we can win over (patayisuvudu) girls...In that film, the boy pretends to be studious and makes the girl fall for him... in this way, we can act as though we are good and win over (patayiso) good girls...." (Young man, $2^{\text {nd }}$ year JOC, in depth interview)

Young men also identified with many situations in love films, particularly the dilemmas and concerns involved in declaring their love or deciding the best possible way to do so:

“'Malla' is a super film. Because I am in love, it helps me a lot. I used the songs from this film to write a poem and gave it to my girl. She liked it very much." (Young man, respondent, $3^{\text {rd }}$ year BA) 
"In the end, the hero and heroine are walking down the road and he tells her about his love for her. I really liked this scene very much; I have decided that I will also tell my girl about my love for her in this way." (Young man, respondent, $2^{\text {nd }}$ year JOC)

Young women's narratives, much like those of young men, also highlighted the manner in which the media had provided them cues about ways of dealing with everyday pre-occupations, including heterosexual interactions and ways of supporting the romantic relationships of their peers.

One young woman explained how watching daily soaps on TV provided her with "useful information" on how to handle a love relationship, support peers in a romantic relationship, and to cope with the problems that she may encounter with her future in-laws:

"It is nice to watch serials. It is very real like our own life. For example, the husband chasing the wife out of the house, quarrels between the daughter-in-law and mother-in-law.... These are things that we see around us... watching this I learn about the kinds of problems I may have to face in my life in the future... and understand how to deal with them.... I get a lot of useful information also. If the story has lovers, you can see how they show their love for each other, how they get married, how they convince their parents. This information is useful to me...." (Young woman, $1^{\text {st }}$ year PUC, in-depth interview)

Apart from scripts such as those reported above, several young women shared their desire to imitate the looks and mannerisms of their favourite film characters as these quotes indicate:

"I feel like behaving like the film actresses-the way they dress and dance. I like Ramya because of her nice hair. I wish I had that kind of hair. I like to wear make-up like her. She puts on lots of lipstick. I like that...." (Young woman, $2^{\text {nd }}$ year JOC, in-depth interview)

"My friends tell me I look like Suhasini. I want to learn to laugh like her. I plait my hair like her so I look like her." (Young woman, $2^{\text {nd }}$ year BA, in-depth interview)

"I like her hairstyle - she parts it on one side and the way she keeps pushing her hair back. She acts very well in love films. I would like to have her kind of figure and hairstyle. But I can only desire it but cannot fulfill it. I am short and have curly hair...." (Young woman, $1^{\text {st }}$ year JOC, in-depth interview)

That the Indian cinema also provides adolescents with cues for romance and fashion has also been reported by the 2003 WHO study. For example, FGD findings of the study cite:

"Films do influence us... we try to act like them... try to win a girl using methods we have seen heroes use. Try to be good like the hero.... Try to copy his dress style", and further, "in college it is necessary to have a girlfriend. It's a fashion" and "if a guy does not have a girlfriend, he is jealous of others who do... and he gets teased." (WHO, 2003). 


\section{Influence of friends}

Peers clearly played an important role in influencing behaviour change among both young men and young women. For example, $38-54 \%$ of young men and $47-64 \%$ of young women who reported recent changes in dressing style and mannerisms, 19-44\% and $25-40 \%$, respectively, who reported recent changes in interactions with the opposite sex, and $57-59 \%$ of young men who had recently started smoking or drinking alcohol attributed these changes to peer influences. Indeed, findings show that at least three out of every five of the young men who were currently using tobacco and alcohol had initiated the behaviour recently and the largest proportions among them had initiated substance use as a result of peer pressure.

Peer influences were also held responsible by largest proportions of young women for behaviours related to teasing, winning over young men, and particularly, for falling in love. Indeed, seven out of every ten young women who were in love at the time of the survey, reported falling in love to be a recent occurrence, and two-fifths of these young women claimed that it was influenced by their peers.

In-depth interviews of young women confirmed the role played by friends by serving as confidantes, sounding boards and go-betweens thus:

“...because I help my friends and their boyfriends... I encourage and help them ...like passing love letters between them...." (Young woman, $1^{\text {st }}$ year PUC, in-depth interview)

One of the young women reported consulting her friend about her feelings for a boy whose response she was unsure of as follows:

"I like one of the boys in my college...we smile at each other. I want to tell him that I like him. But I am scared-what if he says he does not feel the same way? ...I asked what I should do. She said if I like him, I should go and talk to him and not pine away like this...." (Female, $1^{\text {st }}$ year PUC, in-depth interview)

Similarly a young man reported how he relies on his friends' support to convince his girlfriend's family about his relationship with her, and as a last resort if things do not work out, to help him elope with her:

"They have said they will help me. They will try and convince the girl's family. But if there are problems like ... if they don't agree, my friends say I should marry her immediately. If I marry her, they have agreed to help me financially as well. My friends will support me in all ways. I haven't told my girlfriend that I am thinking of the two of us running away. If she says no, my friends will convince her." (Young man, PUC $1^{\text {st }}$ year, in-depth interview)

Gender differences were evident with regard to the relative influence of peers versus the media. Among young men, peers were cited less often as the leading influence than were the media (with regard to four and seven of eleven behaviours, respectively; Table 10). Among young women in contrast, more young women attributed recent changes in behaviour to peers (six of nine behaviours) than to the media (three) (Table 11). 


\section{Influence of the family}

Far fewer young men and women attributed recent changes in behaviours to family influences as compared to the influence of peers and the media. Nevertheless, $8-18 \%$ of young men and $13-32 \%$ of young women held a family member responsible for recent changes in their behaviours. For example, $14-17 \%$ of young men and $20-26 \%$ of young women attributed recent changes in dressing style and mannerisms to family members. Further, while just $8-10 \%$ of young men attributed changes in their interactions with young women to family influences, many more young women (13-32\%) attributed such changes to family influences. Finally, $12-18 \%$ of young men reported that family members had influenced them to start smoking and/or drinking alcohol. We note that family members may have included siblings, cousins, or uncles, who have a more egalitarian rather than authoritative relationship with young people, and are likely to be perceived as peers within the family.

Information gathered from in-depth interviews confirms that for many young women, the family played a more important role than did films and TV, as the following narratives exemplify:

"All serials and films are based on the love theme-the girl and the boy running away and one of them getting murdered. In the film "Heart Beats', The boy and girl fall in love but they do not inform their parents about it. When my parents saw this they got worried that I may also do so. My mother said, 'If you do like that, I will kill you'. I have told her not to worry, that even if I were to fall in love, I would tell everyone and not do it on the sly." (Young woman, $2^{\text {nd }}$ year JOC, in-depth interview)

"In their opinion, if I watch TV, then I will get spoilt (haalagihoguthaale) and that my behaviour will get spoilt. My grandmother says that due to TV people are getting spoilt. In some ways I feel what they say is right." (Young woman, $2^{\text {nd }}$ year JOC, in-depth interview)

Indeed, not only did young women tend to understand parental concerns but they were conscious not to let such influences sway them, and reported that they deliberately avoided certain kinds of films and watching too much TV:

"I never watch Ravichandran's films. They will destroy us. In his films there is a lot of kissing and touching. When boys and girls watch such films their mind (mansu) wavers (chanchala). We might cross our limits and end up getting destroyed. That's why I don't watch such films." (Young woman, $2^{\text {nd }}$ year BA, in-depth interview) 


\section{Summary and conclusions}

This report focuses on the media use patterns of male and female college students, their interpretation of film portrayals, and self-reported changes in attitudes and behaviours that they attribute to media (films and TV), peer and family influences. It draws upon a study of youth in Kanakapura town in south Karnataka that included both quantitative and qualitative components.

Findings suggest considerable exposure to the media-TV and films - among both young men and women - over 2 hours of TV viewing per day, and between 10 and 20 films viewed per month. Gender differences were, however, apparent. For one, young men watched significantly more films in a month than did young women.

Second, young men and women differed significantly in their film and TV preferences; while both young men and women reported enjoying films with love themes, more young men than women preferred films with sexy scenes and rowdyism, and more young women than men preferred films with family themes. Qualitative findings supported these preferences, suggesting that differing issues of interest, situations that paralleled their own, and/or familial concerns guided young men and young women to select the kinds of films they viewed and the content/messages they sought from them. Indeed, the findings highlighted that young women's keen awareness of family and social expectations, and their internalization of their families' apprehensions about the potential 'harmful' influence of films, apparently affected the selection of the kinds of films they watched as well as avoided.

A third gender difference evident from findings of the survey was differing contexts in which young men and women watched films. Clearly, young men were considerably more likely than young women to enjoy the freedom to choose both the venue and the company: far more young men than women watched films in a theatre either alone or together with their friends or a girlfriend, while the majority of young women watched films at home with family members, and if permitted to go to a theatre, only with their female friends. Qualitative data revealed that watching films in a theatre with friends directed young men's attention to the sexual content in films and also provided a context for some interaction with the opposite sex. Most young women, on the other hand, reported feeling constrained by family controls not only in where and with whom they watched films but also in what they watched even at home.

Gender differences were also evident in participant responses to a film clip portraying a situation in which a young woman hits a man who is harassing her. Indeed, responses seemed to be guided by their notions of gender-appropriate behaviour for women. Support from both young men and women for the woman in the film clip was contingent on the fact that she fit into their idea of a traditional woman. However, she lost the support of young men who labeled her a bajari (derogatory term for aggressive women) because her inexcusable act of hitting the man defied traditional notions of acceptable female behaviour. Young women, on the other hand, commended her courage and traditional 
values, but felt that she had taken an extreme step which could invite a bad reputation and violent retaliation from the man. Thus we see that participants had used the larger socio-cultural gender lens to interpret film situations and the appropriateness of behaviours therein.

Respondents were asked whether they engaged in selected behaviours relating to dressing style and mannerisms, interaction with the opposite sex, smoking, and drinking, and had made any recent changes in these behaviours. Overall, young men were significantly more likely than young women to report both engaging in various behaviours and making recent changes in each behaviour explored, suggesting that they were likely freer to adopt a new behaviour than young women, who were more likely to be subject to strict family and social controls. Further, consistent with their greater mobility and exposure to films, young men cited the media more often as the leading influence for behaviour change than their peers (with regard to seven and four of eleven behaviours, respectively). In contrast, more young women attributed changes in behaviour to peers (six of nine behaviours) than to the media (three), perhaps a reflection of their limited mobility and exposure to films on the one hand, and greater association with peers, on the other.

Findings confirm that the media did indeed influence young people's behaviours. Both qualitative and survey findings highlighted the role of films and TV on young people's behaviour, at the same time, demonstrating gender differences. Largest proportions of both young men and women believed that the media had influenced changes in their behaviour related to interaction with the opposite sex. Notably, consistent with their liking for romantic films and those with sex scenes, young men held the media responsible for their recent changes in all five behaviours concerning heterosexual interaction; young women attributed three of the five behaviours to media influence. Significant proportions of young men - almost half-also reported that recent changes in their dressing style and mannerisms had been prompted by the media.

Significantly, qualitative findings revealed the media as a store-house of ideas particularly on heterosexual interaction for both young men and women, and family-related issues for young women. Notably, young men claimed that films with love themes offered inspiration and encouragement to cultivate their romantic interests and relationships, and ways of handling various dilemmas and concerns therein including patao-ing or winning over girls. Young women reported using these scripts particularly for enhancing their friends' romantic relationships by offering counsel and serving as go-betweens. Contrasting with young men's prime preference for romantic films, young women related closely with family-based films/ TV serials with storylines that resonated with their lives, deriving lessons from them to address situations occurring in their day-to-day life; in fact they even tended to store lessons for future use such as those for handling problems that may be encountered with future in-laws.

Thus, both young men and women drew cues from the media of their choice for use in their own situations. These findings seem to endorse the "circular model" proposed by Steele (1999) which recognizes young people as "active audiences" who judge media content "in terms of credibility as well as suitability (of use) for their specific situations and daily life experiences" (Steele, 1999). Additionally, the role of the media in providing guidance on dos and don'ts in the context of heterosexual interaction seems to support the 
idea of a sexual 'super peer' developed by Brown and her colleagues (Brown, Halpern and L'Engle, 2005).

Survey findings also showed that both young men and women used ideas from films to tease those from the opposite sex though considerably larger proportions of young men than young women reported so. Young men reported actively using film scripts to tease girls, translating the ideas into action largely as a means of entertainment in all-male groups, either to impress male peers or to develop heterosexual relationships. Findings show, moreover, that substantial proportions of both young men and women had initiated teasing the opposite sex recently — one out of every four young men and one out of every two young women who currently teased, claimed to have adopted the behaviour only recently; moreover, three-fifths of the young men and half of the young women who reported a recent change attributed it to the media. The most obvious influence of the media, however, was evident among young men who had fallen in love-almost nine out of every ten young men who reported that they were in love, said that the experience was recent.

Thus, while young men seemed to be better able to translate ideas from films into action, young women reported being constrained primarily because of social controls on all aspects of their lives particularly their access to the media, mobility and their choice of friends. Socio-cultural norms that define differential levels of freedom and choice for young men and women seemed to be the over-arching context in which media influence also operated

The media, however, were not the only influence on young people's behaviours; peers seemed to be a more dominant influence than the media in influencing certain behaviours. For example, sizable proportions of young men were engaged in smoking and drinking, and at least three out of every five of these young men reported to have adopted the behaviour only recently, attributing it predominantly to their peers. Peer influences were also reported by large proportions of young women to be responsible for their falling in love. In fact, seven out of every ten young women who were in love, reported falling in love to be a recent occurrence, two-fifths of the latter owing it to peer influences. Qualitative findings of respondents supporting their peers' romantic relationships by acting as sounding boards and go-betweens strengthen this observation.

Respondents also reported peers as the leading influence on behaviours related to dressing style and mannerisms; while peer influences dominated those of the media in effecting changes in all four behaviours related to dressing style and mannerisms among young women, they were almost as effective as the media in influencing these behaviours among young men.

Finally, in contrast to media and peer influences on recent changes in behaviour, the family played a far more muted role for both young men and women. Nevertheless, although modest, family pressures influenced young women, in general, to a greater extent than they did young men. This is particularly evident from qualitative findings that have stressed for example, that young women had internalized their family's concerns about the potential 'harmful' influence of films; so much so that they consciously chose to act in consonance with family expectations and social norms by avoiding the kinds of films that could 'destroy' them. 
This report has added to the growing body of evidence particularly in India of the importance of films and TV in young people's lives. It has also highlighted that films and TV along with peers make a powerful combination particularly among young men. Apart from indicating media consumption patterns, the study also indicates the possible pathways in which ideas from films are translated or not translated into action.

As a next step, it would be important to unpack specific factors associated with media influence among young men and women. A better understanding of these gendered influences will provide important pointers for interventions to use media and peers in creative ways to ensure a healthy and responsible transition into adulthood among young men and women. 


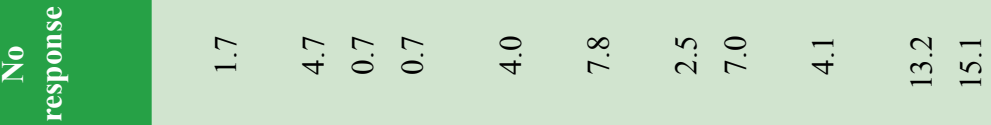

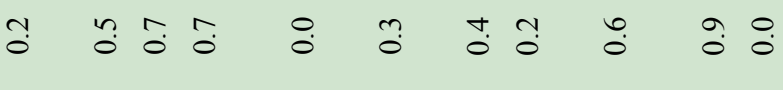

†ำ

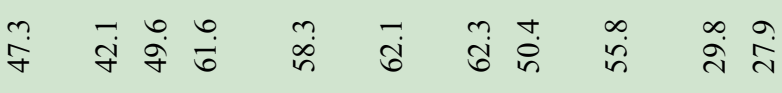

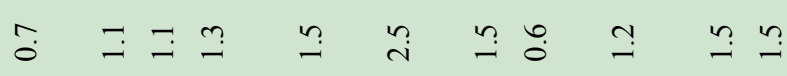

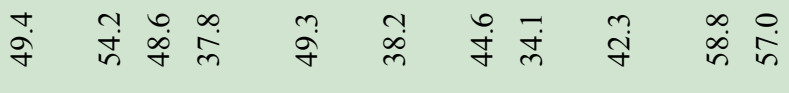




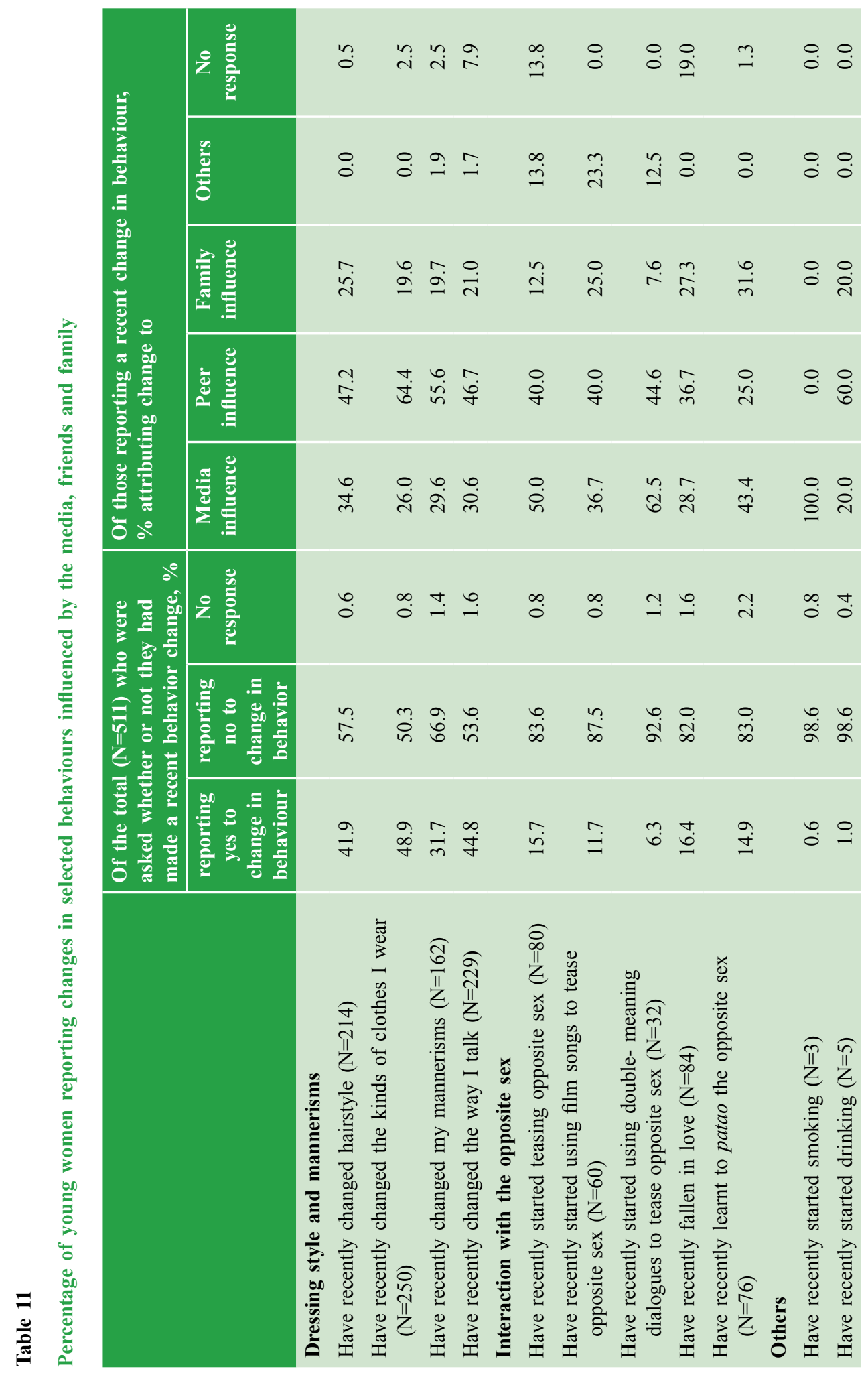

41 Films and TV: Viewing patterns and influence on behaviours of college students 


\section{Acknowledgements}

Several people have supported me all through this project. I am truly grateful to Dr. Pertti J. Pelto for his valuable time, insights and inputs at all stages of the study, Dr. Jayashree Ramakrishna for her guidance, Dr. Saraswathi Ganapathy, Belaku Trust and Ms. Nirmala Murthy, Foundation for Research in Health Systems for generously sharing their offices in Kanakpura and Bangalore respectively. My grateful thanks to Shireen Jejeebhoy for her incisive inputs, patience and understanding and I would also like to thank Shveta Kalyanwala, K.G. Santhya, Francis Xavier and Komal Saxena from the Population Council for all their support throughout the project. I am very grateful to Ms. Jyoti Moodbidri for her careful edits of the paper both for content as well as structure and bringing it to its present form.

Without the support from my able and skillful team, this study would not have been possible. Shakuntala M. Dotihal, Nanjamani CE, Raghavendra and Maruti: thank you very much for your commitment, enthusiasm and involvement. Finally I want to thank the college management for their support and co-operation and to all the study participants who placed their trust in us and shared their stories.

Last but not least, my heartfelt gratitude to my family and friends for their constant encouragement, without whose support this study would not have been possible. 


\section{References}

Abraham, L. 2001. "Redrawing the lakshman rekha: Gender differences and cultural constructions in youth sexuality in urban India," South Asia 24:133-156.

Behera, S.K. 1989. "Gender role biases on Indian television," Media Asia 16(3):119-124.

Belaku Trust, 2004. "Concerns of school-going youth in rural South Karnataka- Insights on reproductive and general health issues" Belaku Trust, Bangalore.

Bhojani, U. 2009. "Study of tobacco use and perceptions about tobacco use and related factors among the pre-university students in Bangalore city," ISEC-SRTT Visiting Fellowship Report, Institute for Social and Economic Change, Bangalore.

Brown, J.D. and S. Newcomer. 1991. "Television viewing and adolescents' sexual behaviour," Journal of Homosexuality 21:77-91.

Brown, J.D., C.T. Halpern and K.L. L'Engle. 2005. "Mass media as a sexual super peer for early maturing girls," Journal of Adolescent Health 36(5):420-427.

Brown, J.D., K.L. L'Engle, C.J. Pardun et al. 2006. "Sexy media matter: Exposure to sexual content in music, movies, television, and magazines predicts black and white adolescents' sexual behavior," Pediatrics 117(4):1018-1027.

Browne, K.D. and C. Hamilton-Giachritsis. 2005. "The influence of violent media on children and adolescents: a public-health approach," Lancet 365:702-710.

Calfin, M.S., J.L. Carroll and J. Schmidt.1993. "Viewing music-videotapes before taking a test of pre-marital sexual attitudes," Psychological Reports 72:475-481.

Corder-Bolz, C. 1981. "Television and adolescents' sexual behaviour," Sex Education Coalition News 3:40.

Dalton, M.A., A.M. Adachi-Mejia, M.R. Longacre et al. 2006. "Parental rules and monitoring of children's movie viewing associated with children's risk for smoking and drinking," Pediatrics 118:1932-1942.

Escobar-Chaves, S.L., S. Tortolero, C. Markham et al. 2004. "Impact of the media on adolescent sexual attitudes and behaviours," Centre for Health Promotion and Prevention Research, University of Texas Health Science Centre, Houston.

Gauntlett, D. 1998. "Ten things wrong with the "effects model," in Approaches to Audiences- A Reader, eds. R. Dickinson, R. Harindranath and O. Linné. Arnold, London. 
Goswami, H. and R. Kashyap. 2006. Tobacco in Movies and Impact on Youth" A study by Burning Brain Society, Chandigarh.

Greeson, L.E. and R.A.Williams.1986. "Social implications of music videos for youths: An analysis of the content and effects of MTV," Youth and Society 18:177-189.

Hanewinkel, R., M. Morgenstern, S.E. Tanski et al. 2008. "Longitudinal study of parental movie restriction on teen smoking and drinking in Germany." Addiction 103:1722-1730.

Hanewinkel, R. and J.D. Sargent. 2008. "Exposure to smoking in internationally distributed American movies and youth smoking in Germany: A cross-cultural cohort study," Pediatrics 121:e108-e117.

Hawk, S.T., L, Vanwesenbeeck, H. de Graaf et al. 2006. "Adolescents' contact with sexuality in mainstream media: A selection-based perspective," The Journal of Sex Research 43(4):352-363.

Heatherton, T.F. and J.D. Sargent. 2009. "Does Watching Smoking in Movies Promote Teenage Smoking?" Current Directions in Psychological Science 18(2):63-67.

International Institute for Population Sciences (IIPS) and Population Council. 2008. Youth in India: Situation and Needs 2006-2007. Mumbai, IIPS.

Jejeebhoy, S. and M.P. Sebastian. 2004. "Young people's sexual and reproductive health," in Looking Back Looking Forward-A profile of Sexual and Reproductive Health in India, ed. S. Jejeebhoy. Population Council, New Delhi.

Joshi, M. 2004. "Sexuality of Adolescent Girls: A study in a low income settlement in Pune City," unpublished doctoral dissertation, School of Health Sciences, University of Pune, Pune.

Kilaru, A. 2004. "Sources of information: Sources that shape the knowledge, attitudes and perceptions of adolescents." Paper presented at the National Conference of the NIMHANS Small Grants Programme on Sexuality and Sexual Behaviour, 9-11 March 2004, Bangalore.

Maslekar, M., K. Hamsa and A. Vasan. 2004. "At the movies: Influence of popular films on adolescent \& behaviour," Paper presented at the National Conference of the NIMHANS Small Grants Programme on Sexuality and Sexual Behaviour, 9-11 March 2004, Bangalore.

National Cancer Institute. 2008. "The role of the media in prompting and reducing tobacco use,” NCI Tobacco Control Monograph No. 19. NIH Pub. No. 07-6242. Bethesda, MD.

Office of the Registrar General and Census Commissioner. 2001. State-wise Literacy Rates. Accessed on 24 July 2010 at http://ssa.ap.nic.in/State\%20wise\%20Literacy\%20 rates\%202001.pdf. 
Peterson, R.A. and J.R. Kahn. 1984. "Media preferences of sexually active teens," Paper presented at the meeting of the American Psychological Association, 26 August 1984, Toronto, Canada.

Ramasubramanian, S. and M.B. Oliver. 2003. "Portrayals of sexual violence in popular Hindi films, 1997-99," Sex Roles 48(7-8):327-336.

Sargent, J.D., T.A. Wills, M. Stoolmiller et al. 2006. "Alcohol use in motion pictures and its relation with early-onset teen drinking," Journal of Studies on Alcohol 67:54-65.

Schwartz, K. 2004. "The influence of wanting to look like media figures on adolescent physical activity,” Journal of Youth Ministry 3(1):97-101.

Shah, P.B., M.S. Pednekar, P.C. Gupta et al. 2008. "The relationship between tobacco advertisements and smoking status of youth in India," Asian Pacific Journal of Cancer Prevention, 9(4):637-642.

Singh, M.M., R. Devi and S.S. Gupta. 1999. "Awareness and health seeking behaviour of rural adolescent school girls on menstrual and reproductive health problems," Indian Journal of Medical Sciences 53:439-443.

Sodhi, G., M. Verma and S.L. Schensul. 2004. "Traditional protection for adolescent girls and sexual risk: Results of research and intervention from an urban community in New Delhi," in Sexuality in the Time of AIDS: Contemporary Perspectives from Communities in India, eds. R.K. Verma, P.J. Pelto, S.L. Schensul et al. Sage Publications, New Delhi.

Steele, J. R. 1999. "Teenage sexuality and media practice: Factoring in the influences of family, friends, and school," The Journal of Sex Research 36(4):331-341.

Strasburger, V.C. and E. Donnerstein. 1999. "Children, adolescents, and the media: Issues and solutions," Pediatrics 103(1):129-139.

The Tribune, Tuesday, 18 March 2003. Chandigarh, India.

Vasan, A., S. Dinesh and C. Prashanth. 2004. "Gandhis, Choolists, All-rounders, Tarlegalu and Bad Boys: Notions of masculinity among male college students," Paper presented at the National Conference of the NIMHANS Small Grants Programme on Sexuality and Sexual Behaviour, 9-11 March 2004, Bangalore.

Wilson, J.D. and M.S. MacGillivray. 1998. "Self-perceived influences of family, friends, and media on adolescent clothing choice," Family and Consumer Sciences Research Journal 26(4):425-443.

World Health Organization. 2003. "Bollywood: Victim or Ally? A Study on the Portrayal of Tobacco in Indian Cinema," World Health Organization, Geneva, Switzerland. 
47 Films and TV: Viewing patterns and influence on behaviours of college students 
